\title{
Psidium guajava Leave Extract for Improving Ultraviolet Protection and Antibacterial Properties of Cellulosic Fabrics
}

\author{
Menna Zayed ${ }^{1}(\mathbb{D})$, Heba Ghazal ${ }^{1}$, Hanan Othman ${ }^{1}$, Ahmed. G. Hassabo ${ }^{2, *(\mathbb{D})}$ \\ Textile Printing, Dyeing and Finishing Department, Faculty of Applied Arts, Benha University, Benha, Egypt \\ 2 National Research Centre, Textile Industries Research Division, Pretreatment, and Finishing of Cellulose-based Textiles \\ Department, 33 El-Behouth St. (former El-Tahrir str.), Dokki, P.O. 12622, Giza, Egypt \\ * Correspondence: aga.hassabo@ hotmail.com;
}

Scopus Author ID: 55909104700

Received: 3.04.2021; Revised: 20.05.2021; Accepted: 25.05.2021; Published: 13.08.2021

\begin{abstract}
Nowadays, many types of research are looking for natural products to be used in several applications, particularly in the medical field. Psidium guajava Leave Extract was therefore used to impart multi-functional properties to cotton fabrics, such as antibacterial and antioxidant properties, in addition to ultraviolet protection. Two solvents have been used for the preparation of the extract, namely water, and ethanol. Both prepared extracts were used as a reducing and stabilizing agent in the synthesis of silver nanoparticles. Prepared extracts and synthesized nanoparticles have been characterized using a variety of techniques, such as total phenol content, antioxidant activity, particle size, FTIR, and TEM, and these techniques provide the extraction and synthesis of silver nanoparticles. The optimization of the treatment condition of cotton fabrics was evaluated at different concentrations, $\mathrm{pH}$, time, and temperature. The assessment shows that the optimum condition for the treated cotton fabric has been achieved by using $100 \%$ of the extract at $\mathrm{pH} 8$ for $15 \mathrm{~min}$ at $70^{\circ} \mathrm{C}$. Monitoring was assessed as a UPF value. Antimicrobial results for treated tissues showed that Gram-negative bacteria showed less sensitivity to both extracts than Gram-positive bacteria, while fungal strains showed high sensitivity to both extracts. The antioxidant properties of the treated fabrics may also improve, allowing them to be considered in medical applications.
\end{abstract}

Keywords: cotton fabric; Psidium guajava Leave Extract; antibacterial, Antioxidant, and Ultraviolet protection

(C) 2021 by the authors. This article is an open-access article distributed under the terms and conditions of the Creative Commons Attribution (CC BY) license (https://creativecommons.org/licenses/by/4.0/).

\section{Introduction}

Cotton is the most natural fiber commonly used for textiles due to its softness, breathability, low price, the efficiency of regeneration, and easy mass production [1]. However, cotton is an excellent medium for the growth and spread of harmful microorganisms such as bacteria, fungi, and yeast under appropriate nutrient, moisture, and temperature conditions. Harmful growth of the microorganism results in staining, unpleasant odor, discoloration, loss of mechanical properties, and/or health-related problems.

Scientific advancement is currently developing innovative textile auxiliaries to produce high-performance textile functional finishes with excellent antimicrobial activity. Consumers are becoming more aware of and more concerned about the safety of auxiliaries [2]. Many commercial auxiliaries with a range of antimicrobial properties are currently available on the 
market under different trade names in the textile industry. These auxiliaries are made of synthetic materials such as phenols, quaternary ammonium salts, and organosilicons [3].

While synthetic agents are highly effective, they are harmful to human health. Therefore, natural auxiliaries are considered a substitute for synthetic ones used in the functionalization of textile materials.

Psidium guajava Linn is a common plant, called guava, and is available worldwide [4]. Guava has been shown to have many biological activities as a medicinal plant, including anticough, anti-diabetes, antibacterial and antioxidant properties. Pharmacological and chemical research work has been carried out on the leaf as it is enriched with phytoconstituents, including flavonoids and phenols, including terpenoids, chlorophyll, tannins, saponins, and essential oils [3].

Aqueous and alcoholic extracts of Psidium guajava leaves have been shown to have inhibitory properties against Staphylococcus aureus (S. aureus), Streptococcus mutans ( $S$. mutans), Pseudomonas aeruginosa (P. auruginosa), Salmonella enterica subsp. Enterica ( $S$. enteritidis), Bacillus cereus (B. cereus), and Escherichia coli (E. coli) are growing. Its antimicrobial performance could therefore be beneficial as an antimicrobial agent for technical textiles [5]. In the context of the ecological environment, researchers have explored ways to incorporate nanoparticles (NPs) into fiber and produce antimicrobial textile products.

Due to the awareness of safety and hygiene, multi-functional fabrics have increased considerably over the last few years. The demand for nanoparticles (NPs)-coated fabrics, in particular antimicrobial-potential fabrics, has increased. The coating of NPs on the cotton fabric surface was performed using various techniques, such as sun-freezing, sonochemistry, and pad dry-curing [6].

Nanotechnology is one of the most active areas of research. Nanoparticles have distinct properties compared to bulk types of the same substance based on their particular characteristics, such as size, distribution, and morphology. A nanoparticle (nano-powder, nanocluster, or nano-crystal) is a microscopic particle less than $100 \mathrm{~nm}$ in at least one dimension [7].

Silver nanoparticles can be synthesized through various pathways, such as chemical reduction, microwave, and green pathway procedures [8]. But there are several problems associated with chemical methods. Therefore, a great deal of attention was paid to the green route method of nanoparticle synthesis as an alternative method for synthesizing nanoparticles due to its cost-effectiveness and the reduction in the use of hazardous chemical compounds [9]. AgNPs biosynthesis through the green route was a promising field in nanotechnology due to the use of active Phyto-compounds used as a reducing and capping agent $[6,10,11]$.

Protective textiles have become an important part of modern textiles. It has referred to clothing and other fabric-related objects intended to shield the wearer from adverse environmental conditions resulting in injury or death. Since protective fabrics often have to tolerate the effects of many harsh conditions, such as intense heat and cold [12-15], fireresistant [16-19], water and oil repellent [20], hazardous chemicals and gasses [21], bacterial/viral safety [22-29], mechanical risks, wound dressing [30-34], electrical conductivity [35], $\mathrm{pH}$, thermo-sensitive, etc.

In some cases, these textiles may be used to protect the air or wastewater from contamination, such as clean rooms [36], and dust adsorption [21], heavy metals or dyes $[37,38]$. The introduction of emerging technology to improve efficiency and comfort in sportswear design needs to be discussed from second-skin to outerwear [39]. 
According to international requirements, UV-protective shields are categorized into separate UPF levels based on their UPF assessment (excellent; above 40, very good; between 25-39 and good; between 15-24) [40-43]. After 10 minutes of prolonged exposure to UV solar radiation, UPF defense shields equal to 15 times increase the exposure time, i.e., $150 \mathrm{~min}$ [44]. Higher UPF values greater than $40(40+)$ or $50(50+)$ are considered protected.

The objective of this study was to investigate the UV protection properties and antibacterial activity of Psidium guajava leaf extract treated cotton in the presence and absence of synthesized extracted AgNPs. The process may therefore be ideal for the use of bio-friendly materials in the production of nanoparticles. The synthesis of AgNPs was carried out through a biological reduction using the extract of Psidium guajava leaves, which provides an effective capping agent for the stability and viability of the synthesized nanoparticles.

\section{Materials and Methods}

\subsection{Materials.}

Bleached scoured cotton fabric $\left(220 \mathrm{~g} / \mathrm{m}^{2}\right)$ supplied by Ghazel El-Mahala for Textile Industry Co., Egypt, was used during this research. Psidium guajava Leaves (Psidium guajava L.) were purchased from the local market in Egypt. Ethanol (95\%), acetic acid, sodium carbonate, citric acid, sodium hypophosphite (SHP), silver nitrate, and sodium carbonate were provided from Fluka. Folin-Ciocalteau reagent purchased from Sigma Chemicals Co., tannic acid, methanol, and sodium carbonate $\left(\mathrm{Na}_{2} \mathrm{CO}_{3}\right)$ were purchased from Merck. All the chemicals and reagents were used as received without purification.

\subsection{Methods.}

2.2.1. Preparation of Psidium guajava leaves (Psidium guajava L.) extract.

The naturally fresh leaves of Psidium guajava were thoroughly washed and cleaned using tap water to remove dust and any particulate matter. The fresh and clean Psidium guajava L. were cut into small pieces. Two solvents, namely water and ethanol, were used in the extraction occurred to Psidium guajava L. to obtain different extraction solutions. Aqueous extraction, $100 \mathrm{~g}$ of Psidium guajava L. was placed in $1000 \mathrm{ml}$ of distilled water and heated to $100^{\circ} \mathrm{C}$ for $60 \mathrm{~min}$. After that, the extract was subjected to vacuum filtration using Whatman filter paper No.1. then, the extraction was stored at $4{ }^{\circ} \mathrm{C}$. The filtrate was used without any further purification. Alcoholic extraction, $200 \mathrm{~g}$ of Psidium guajava $\mathrm{L}$. was placed in $1000 \mathrm{ml}$ of ethanol and heated to $70^{\circ} \mathrm{C}$ for 4 hours in the Soxhlet system, and then the extraction was filtered with the help of Buchner funnel and Whatman No. 1 filter paper. And it was stored at $4^{\circ} \mathrm{C}$. The filtrate was used without any further purification [45].

\subsubsection{Synthesis of silver nanoparticles (AgNPs) using Psidium guajava L. extract.}

$10 \mathrm{ml}$ from each Psidium guajava L. extract (water or ethanol) were added to aqueous $\mathrm{AgNO}_{3}\left(90 \mathrm{ml} ; 0.02 \mathrm{M}\right.$ ) for $10 \mathrm{~min}$ at $80^{\circ} \mathrm{C}$. The $\mathrm{pH}$ medium was changed from 6 to 10 to monitor the best condition for synthesizing silver nanoparticles (AgNPs). In the beginning, the color of the solution was changing from yellow to dark brown, indicating the start formation of AgNPs is of the solution mixture. The synthesized nanoparticle was further confirmed using a UV-vis spectrophotometer between 300 and $800 \mathrm{~nm}$ [46]. 
2.2.3. Treatment of cotton fabric with Psidium guajava L. extract.

The cotton fabric was cut into $20 \times 20 \mathrm{~cm}$, and then the fabric was washed using a nonionic detergent and air-dried. The cotton fabric was immersed in a solution consists of $10 \mathrm{~g} / \mathrm{l}$ citric acid and $5 \mathrm{~g} / \mathrm{l}$ sodium hypophosphite for $5 \mathrm{~min}$ at room temperature (they were used as cross-linkers to anchor the extract to the cotton fabric), padded to remove excess solution, and air-dried. Thereafter, Cotton fabric was immersed in Psidium guajava L. extract at varying parameters. To find the treatment's optimum conditions, a series of trials were conducted following parameters such as $\mathrm{pH}$, time, and temperature. Sodium carbonate was used to adjust the $\mathrm{PH}$.

Treatment of cotton fabrics has been occurred using both extractions (water and alcoholic) at different $\mathrm{pH}(4,6,8$, and 10), different time $(5,10,15,20 \mathrm{~min})$, and different temperatures $\left(25,50,70\right.$, and $\left.100^{\circ} \mathrm{C}\right)$.

\subsection{Analysis and measurements.}

2.3.1. UV-Visible spectroscopy measurement.

Reduction of silver nitrate to silver nanoparticles using Psidium guajava L. extract is monitored using a JASCO UV-visible absorption spectrophotometer between 300 and $600 \mathrm{~nm}$.

2.3.2. Fourier transform infrared (FT-IR).

The FT-IR of the treated and untreated samples was evaluated using the JASCO spectrometer tester.

\subsubsection{Transmission electronic microscopy (TEM).}

Transmission Electron Microscopy (TEM) images for Psidium guajava L. extracts and synthesized silver nanoparticles were investigated with a JEOL JEM-1200 EX transmission electron microscope operating at $120 \mathrm{kV}$.

\subsubsection{Scanning Electron Microscopy (SEM).}

SEM studied were carried out using a scanning electron - JSM 5400 instrument (Joal, Japan). The specimens in the form of fabrics were mounted on the specimen stabs and coated with a thin film of gold by the sputtering method.

\subsubsection{Particle size analyzer.}

The size of the synthesized AgNPs was characterized by laser particle size analyzer MasterSizer/2000 (MALVERN Instruments, UK) according to ASTM E11:61 [47], ISO 33101:2016 [48], and ISO 565: 1990 [49].

\subsubsection{Assessment of antioxidant property.}

The bioactive Psidium guajava L. extract's antioxidant properties were monitored through the radical scavenging capability on 2,2-diphenyl-2-picrylhydrazyl (DPPH) [50-52]. 


\subsubsection{Determination of total phenolics.}

The total phenolic content in both Psidium guajava L. extracts was calculated by the Folin-Ciocalteau method with some modifications [53,54]. $0.5 \mathrm{ml}$ of the extract was added to $2.5 \mathrm{ml}$ of $0.2 \mathrm{~N}$ Folin-Ciocalteau reagents under stirring for $5 \mathrm{~min} .2 \mathrm{ml}$ of $\mathrm{Na}_{2} \mathrm{CO}_{3}(75 \mathrm{~g} / \mathrm{l})$ was then added. The total volume was completed to $25 \mathrm{ml}$ with distilled water. This solution was kept for incubation at room temperature for $2 \mathrm{~h}$. Absorbance was measured using the JASCO UV-visible absorption spectrophotometer at $760 \mathrm{~nm}$. The standard calibration curve was produced using different concentrations of tannic acid $(0-800 \mathrm{mg} / \mathrm{l})$. The total phenolic content expressed in mg of tannic acid equivalents (TAE) per g of extract.

\subsubsection{The UV-protection factor (UPF).}

The UV-protection factor (UPF) for untreated and treated cotton fabric samples was determined by the Australian/New Zealand standard (AS/ NZS 4366-1996). Using a UV spectrophotometer, the UV-protecting factor (UPF) of the treated fabrics was studied by absorption spectroscopy [55]. The measurement of the control reference was as air. The efficiency of UV (UPF) treated fabric was determined by calculating the absorption, transmission, and reflection of UV. The UPF value was determined using the following equation from the transmission spectra of the fabric samples within the range $280-400 \mathrm{~nm}$ [56$60]$.

$$
\mathrm{UPF}=\frac{\int_{\lambda 2}^{\lambda 1} \mathrm{E}(\lambda) \times \boldsymbol{S}(\lambda) \times \Delta(\lambda)}{\int_{\lambda 1}^{\lambda 2} \mathrm{E}(\lambda) \times \boldsymbol{S}(\lambda) \times \mathrm{T}(\lambda) \times \Delta(\lambda)}
$$

The control relation was calculated as the air where $\lambda \mathbf{1}$ and $\lambda \mathbf{2}$ were equivalent to 280 and $400 \mathrm{~nm}$ respectively, $\boldsymbol{E}(\lambda)$ being the relative erythemal spectral effectiveness, $\boldsymbol{S}(\lambda)$ being the solar spectral irradiance in $\mathrm{W} \mathrm{m}^{-2} \mathrm{~nm}^{-1}(\lambda)$ and $S(\lambda)$ were derived from the National Oceanic and Atmospheric Administration (NOAA) database), $\boldsymbol{T}(\lambda)$ being the spectral transmission of the sample obtained from UV spectrophotometric experiments and $\Delta(\lambda)$ is the difference between measurable wavelengths.

\subsubsection{Mechanical properties of the treated fabric.}

Tensile strength and elongation at break are conducted on a tensile strength apparatus type FMCW 500 (Veb Thuringer Industrie Werk Rauenstein $11 / 2612$ Germany) at $25^{\circ} \mathrm{C}$ and $65 \%$ relative humidity according to the ASTM Test Method D1682-59T [61]. The dry crease recovery angle (CRA) was measured according to AATCC Test Method 66 - 2014 [62]. Fabric roughness was measured using Surface Roughness measuring instrument SE 1700 using ASTM Test Method D 7127 - 13 [63]. Stiffness was performed using the cantilever apparatus according to ASTM test method D 1388-14e1 [64].

\subsubsection{Antibacterial activity.}

The antibacterial activity was quantitatively tested against Staphylococcus aureus (ATCC 29213) as a gram-positive bacteria and Escherichia coli (ATCC 25922) and Candida Albicans (ATCC 10231) as a fungus [65].

Test methods are conducted under standardized conditions to assess the antimicrobial potency of natural textiles. In general, both qualitatively and quantitatively, antimicrobial 
processes are evaluated using conventional tests. Any of the AATCC textile standards available and commonly used are as follows: the AATCC 100-2004 (bacterial reduction method) [66] is a popular methodological model for antimicrobial textile studies. In this test, the uniform concentrate ion test microorganism in liquid culture is cultivated. This cultivation is dissolved into a sterilized nutrient solution. Microorganisms inoculate the untreated and treated fabrics in sealed containers for 24 hours at $37^{\circ} \mathrm{C}$. Shake 1 minute after incubation and then observe microbial concentrations. Finally, the sum of the microbial concerning the original concentration has been determined as reduction percent of bacteria (R\%) as follows [67]:

$$
\text { Percent reduction of bacteria }(\mathrm{R} \%)=\frac{B-A}{B} \times 1000
$$

where $\mathrm{A}$ is the number of recovered bacteria from the inoculated test specimen in the jar incubated during the desired contact duration and $\mathrm{B}$ is the number of bacteria recovered directly after inoculation from the inoculated measured specimen in the jar (at " 0 " contact time).

The method of disc diffusion to analyze the antimicrobial activity of treated fabrics has been used through the AATCC Test Method (147-2016). [16,58,68,69] Squares of $1 \mathrm{~cm}^{2}$ of each fabric are prepared in an aseptic manner to test the antibacterial properties of the treated fabrics as Bershteein et al. [70] by testing the diameter of the inhibition zone (r) [71]. The 0.5 $\mathrm{ml}$ from suspension agar ( $45 \mathrm{ml} / \mathrm{L}$ Nutrient agar) was put in a petri-dish with $100 \mu \mathrm{L}$ of each examined bacterium, and the petri-dish was seeded and solidified, and then pieces of treated fabrics squares were put in the plate. The test plates incubate at $37^{\circ} \mathrm{C}$ for $24 \mathrm{~h}$. the diameter of the inhibition zone (r) was measured in millimeters, then the area of inhibition zones was calculated according to the following equation area of the zone inhibition $\left(\mathrm{mm}^{2}\right)=$ total area fabric area.

\subsubsection{Durability.}

The durability of the treated fabric was evaluated after washing the treated cotton fabric with $2 \mathrm{~g} / \mathrm{L}$ non-ionic detergents (Hostapal) for $10 \mathrm{~min}$ at $40^{\circ} \mathrm{C}$ and then drying at $100^{\circ} \mathrm{C}$ for 3 $\min$

\section{Results and Discussion}

In the presence of Psidium guajava L extract as a capping agent, the preparation of nanoparticles of zinc oxide was studied hydrolyzed with sodium carbonate at various $\mathrm{pHs}$. Also, the produced ZnONPs were characterized using a TGA, XRD, and TEM.

\subsection{Characterization of Psidium guajava L extract and synthesized AgNPs.}

Guava leaves consist of several bioactive molecules, including phenols, flavonoids, and essential oils, considered natural compounds that provide desirable health benefits. Guava leaf compounds that are biologically active are solvent-soluble. The difference in solvent polarity will affect the solubility and extraction yield of the chemical components. Therefore, selecting the correct solvent is one of the most critical steps to improve the extraction process.

Different solvents were studied to find the excellent solvent during extraction to investigate the influence of the solvent on the extractor material and the properties of the guava leaf extract. Total yield extract, total phenol in different solvents of guava leaf extract were investigated. Ethanol and water solvent were provided (2.6 and $2.4 \%)$, respectively. There 
were very similar findings in water as a high polar solvent and ethanol as a low polar solvent. The results have shown that the ethanol extract showed a high total amount of phenolic content $(136.5 \pm 0.37)$ compared to water extract $(132.4 \pm 0.34)$. It is known that high phenolic extracts are responsible for the high activity of antioxidants due to the activity of scavenging.

Moreover, both Psidium guajava L extracts, exhibited higher antioxidant activity (96 \pm 1.5 and $97 \pm 0.8$ for ethanol and water extract, respectively) because the extracts containing high amounts of total phenol content showed high scavenging activity.

Several kinds of research provide that dissolving the endogenous compounds of the plants is the solvent's responsibility [51,72]. Phenolic, known as a polar compound, is more soluble in polar solvents due to the presence of a hydroxyl group in their molecular structures. Polar solvents such as ethanol and water have been more efficient in extraction than non-polar solvents. The hydrogen bonding of a polar solvent can easily interact with the hydroxyl phenolic group.

It is reported before that the identification of the Psidium guajava Leave Extracts indicated that it is a rich source of a phenolic compound that could play the main role in the bio-reduction of metal ions $\left(\mathrm{M}^{+}\right)$to metal nanoparticles $\left(\mathrm{M}^{\mathrm{o}}\right)$. The phenolic compounds extracted from Psidium guajava Leave facilitate the reduction of $\mathrm{Ag}^{+}$and stabilization of $\mathrm{Ag}^{+}$ to AgNPs due to the electron-donating ability of these phenolic compounds [73].

As these phenolic compounds owing to hydroxyl or carboxyl groups in chemical structure, When the metal ions solution $\left(\mathrm{M}^{+}\right)$is added to the extracted solution, the metal ions are adsorbed onto the phenolic compounds owing to the electrostatic interaction between $\mathrm{M}^{+}$ ions and negatively charged alcoholate and/or carboxylate groups. These attraction forces lower the mobility of $\mathrm{M}^{+}$, promote the formation of metal nuclei and control their development $[74,75]$.<smiles>[R]c1ccc(O)c(C(=O)O)c1</smiles><smiles>[R]c1ccc(O)c(O)c1</smiles>

Scheme 1. A possible suggested mechanism for the reduction of $\mathrm{Ag}+$ by phenolic acid compound

Therefore, when silver nitrate solution is added to Psidium guajava Leave Extracts, $\mathrm{Ag}^{+}$ will be firstly adsorbed onto the phenolic compound due to the heavy metal adsorption capacity and physical stability. Then the $\mathrm{Ag}^{+}$will be reduced to $\mathrm{Ag} 0$ by electrostatic interaction of electron-rich oxygen atoms in hydroxyl and carboxylic groups [76,77].

The possible suggested mechanism for reducing $\mathrm{Ag}^{+}$by the phenolic acid compound is presented in Scheme 1. Multiple hydroxyl groups present in the phenolic compound of OP may participate in the reduction reaction. The $\mathrm{Ag}^{+}$ions can form intermediate complexes with hydroxyl $(\mathrm{OH})$ groups present in phenolic acid and then reduced to AgNPs by accepting an electron from a suitable electron donor leaving phenolic acid into its quinone or quinonoid form. 
The UV-Vis spectra of synthesized silver nanoparticles using Psidium guajava L. extract as a reducing and stabilizing agent were observed and illustrated in Figure 1. The UVVis spectrum of the colloidal solution of Silver Nanoparticles has a peak absorption of $460 \mathrm{~nm}$, which is the characteristic peak for AgNPs. Also, the $\mathrm{pH}$ medium affects the synthesis of AgNPs in both extracts.

The color shift in 10 minutes from yellow to dark brown suggests the formation of silver nanoparticles (AgNPs). [78] Moreover, the $\mathrm{pH}$ media impacts the $\mathrm{pH}$ media by increasing the $\mathrm{pH}$ to make the initial solution for both aqueous and ethanol extracts more darkly brown within $10 \mathrm{~min}$. It is clear that in the acidic medium at low $\mathrm{pH}(\mathrm{pH} 4)$, there is no affinity to synthesize AgNPs in both extracts, while increasing the $\mathrm{pH}$ medium to 6 causes the formation of AgNPs. The synthesized AgNPs were increased as the $\mathrm{pH}$ medium increased in both extracts. Besides, the formation of AgNPs in the alcoholic extract is higher than in the water extract.

Due to the polydisparities of nanoparticles, the strong plasmon resonance at $417 \mathrm{~nm}$ increases remarkably with an increased $\mathrm{pH}$ intensity [46,79]. Increased $\mathrm{pH}$ for water extract also has no beneficial impact on the amount of AgNPs. It is the responsibility of agglomerating particles at a high $\mathrm{pH}$ medium [80,81].

Figure 2 shows the particle size of Psidium guajava L. extract in water and alcohol as well as those of the synthesized AgNPs at different $\mathrm{pH}$ media $(6,8$, and 10). The particle size of the synthesized AgNPs decreases by increasing the $\mathrm{pH}$ medium. This could be ascribed to the deposited effect of Psidium guajava L. components on the AgNPs surface. Besides, AgNPs aggregates and cause a decrease in the particle size.

It is also observed that the particle size of Psidium guajava L. extract in water and alcohol is 549 and $235 \mathrm{~nm}$, respectively. It is further noted that the particle size of the synthesized AgNPs with Psidium guajava L. extract in water is higher than those in alcohol in different $\mathrm{pH}(6,8$, and 10) mediums. Thus, the particle size for synthesized AgNPs in an aqueous medium was 120,46 , and $5 \mathrm{~nm}$ in $\mathrm{pH} 6,8$, and 10, respectively, while the particle size of AgNPs in the alcoholic medium was 91,35, and $5 \mathrm{~nm}$ in $\mathrm{pH} 6,8$ and 10 respectively.

Psidium guajava L. extract in water and alcohol are being evaluated by FT-IR and their spectrums are seen in Figure 2. The FT-IR spectrum of Psidium guajava L. extract in water shows a peak in the range of $3390-3450 \mathrm{~cm}^{-1}$, the broadband is due to $\mathrm{O}-\mathrm{H}$ stretching and $\mathrm{N}$ $\mathrm{H}$ of the fatty acids, carbohydrates, and lignin units contained in the leaf of Psidium guajava [81]. Besides, the $\mathrm{C}-\mathrm{H}$ bond in the $\mathrm{CH}_{2}$ group provides a peak that occurs at 2930 and 2860 $\mathrm{cm}^{-1}$ for asymmetric and symmetric stretching, respectively.

There are some overlapping of alternating bands that are due to $\mathrm{C}=\mathrm{O}$ stretching between 1745 and $1625 \mathrm{~cm}^{-1}$. The carbonyl group could be a part of the fatty acid $\left(1740\right.$ and $1720 \mathrm{~cm}^{-}$ ${ }^{1}$ ) or amides $\left(1655 \mathrm{~cm}^{-1}\right)$. Also, there is a stretching peak at $1585 \mathrm{~cm}^{-1}$ attributable to $\mathrm{C}-\mathrm{N}$ bonding.

FT-IR of Psidium guajava L. extract in ethanol exhibits the presence of the recorded characteristic peak at $3450-3220 \mathrm{~cm}^{-1}$ attributed to $\mathrm{O}-\mathrm{H}$ and $\mathrm{N}-\mathrm{H}$ stretching of phenols, alcohols, primary or secondary amine, and/or amide that typically occurs in this region.

Furthermore, there is a noticeable small shoulder band between $2750-2500 \mathrm{~cm}^{-1}$ due to carbonyl $\mathrm{C}=\mathrm{O}$ in the form of $\mathrm{H}-\mathrm{C}=\mathrm{O}$. Another band between 1750 and $1625 \mathrm{~cm}^{-1}$ in the form of aliphatic ketones or esters due to aliphatic $\mathrm{C}=\mathrm{O}$ bonds. Also, the Psidium guajava $\mathrm{L}$. displays an asymmetric band at $1500-1375 \mathrm{~cm}^{-1}$ leading to $\mathrm{N}-\mathrm{O}$ stretching from aliphatic nitrogen [82]. Also, there is an absorption peak at $1235 \mathrm{~cm}^{-1}$ due to a $\mathrm{C}-\mathrm{O}$ stretch from alcohol or phenol. 
Another important peak at $1168 \mathrm{~cm}^{-1}$ is due to a chemical bond between the aromatic ring and oxygen.

Figure 3 shows the TEM images of Psidium guajava L. extract in water and alcohol as well as those of the synthesized AgNPs at different $\mathrm{pH}$ media $(6,8$, and 10). TEM images are shown as a spherical form of good distribution. The TEM study shows that for Psidium guajava L. extract in water and ethanol at $\mathrm{pH}$ 6, the particles have small distribution ranges of 120 and $90 \mathrm{~nm}$, respectively. TEM images reveal that small, spherical nanoparticles about $5 \mathrm{~nm}$ in size are aggregated by increasing $\mathrm{pH}(\mathrm{pH} 10)$ during AgNPs synthesis.
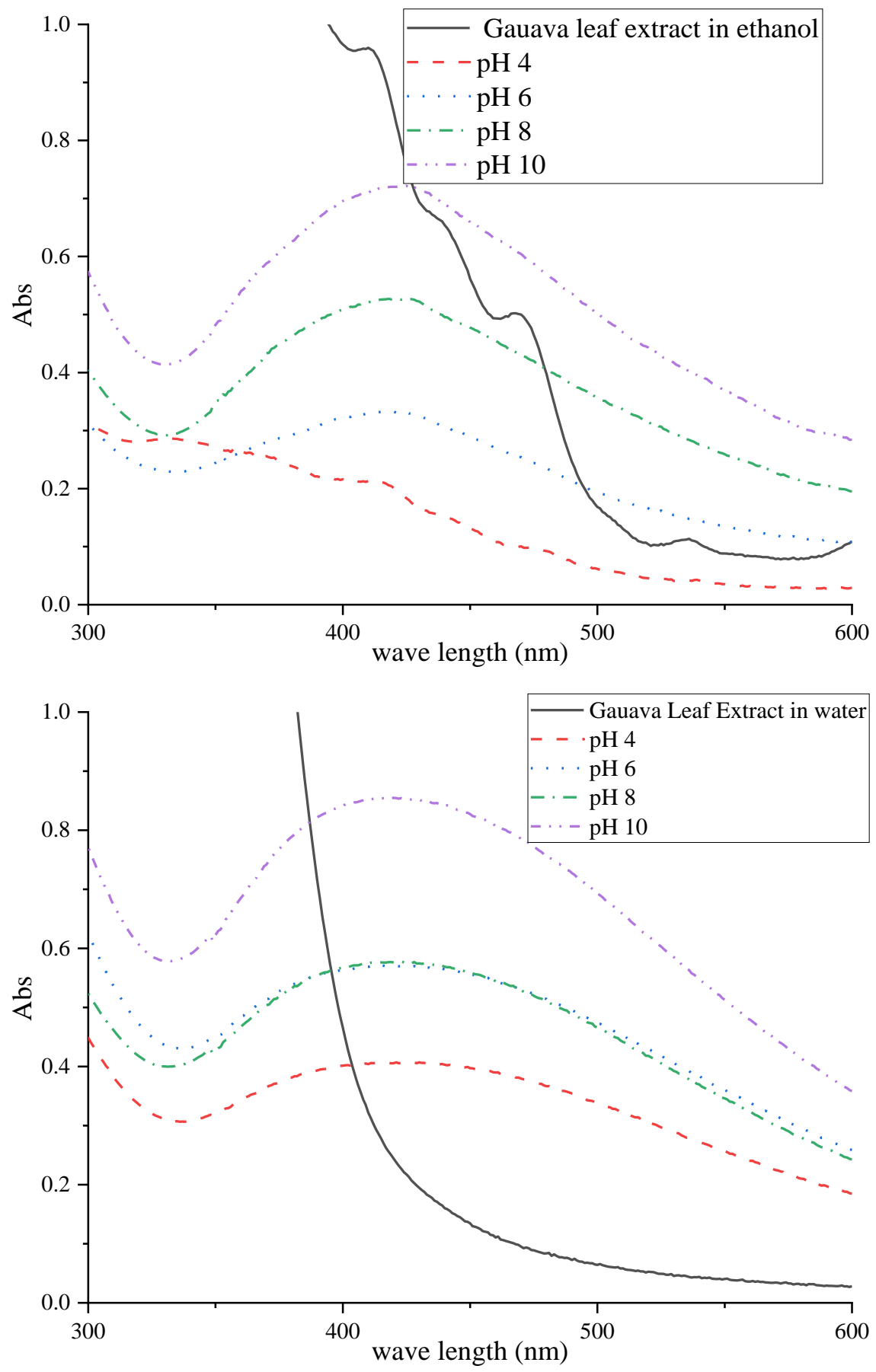

Figure 1. UV spectra for Psidium guajava L. extract in water and ethanol and synthesized AgNPs in both extracts at different pH. (a) UV spectra for Psidium guajava L. extract in ethanol; (b) UV spectra for Psidium guajava L. extract in water. 

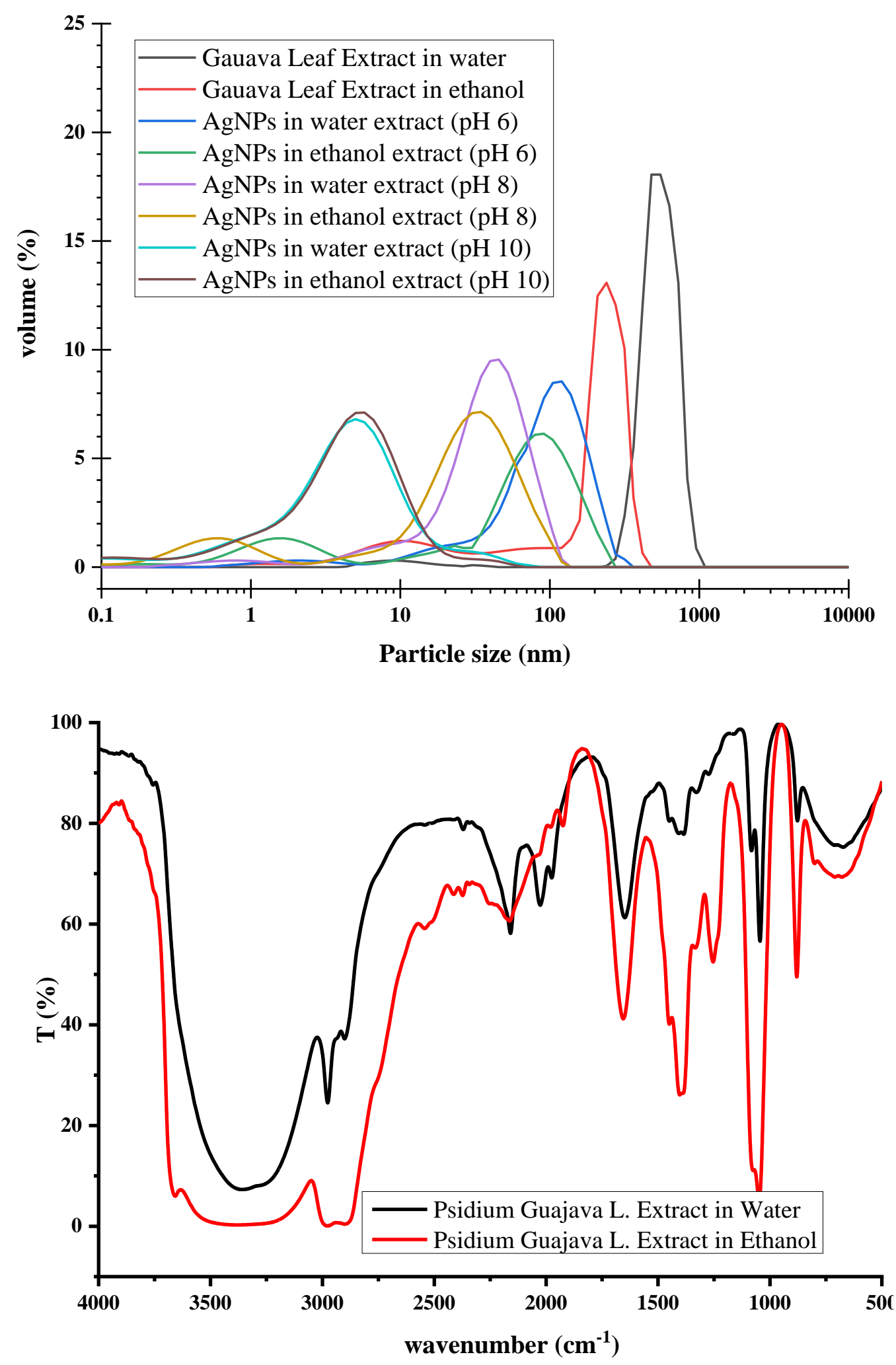

Figure 2. Particle size and FT-IR spectra for Psidium guajava L. and synthesized AgNPs in both extracts at different pH. (a) particle size for Psidium guajava L. extract in water and ethanol at different pH; (b) FT-IR spectra for Psidium guajava L. extract in water and ethanol. 

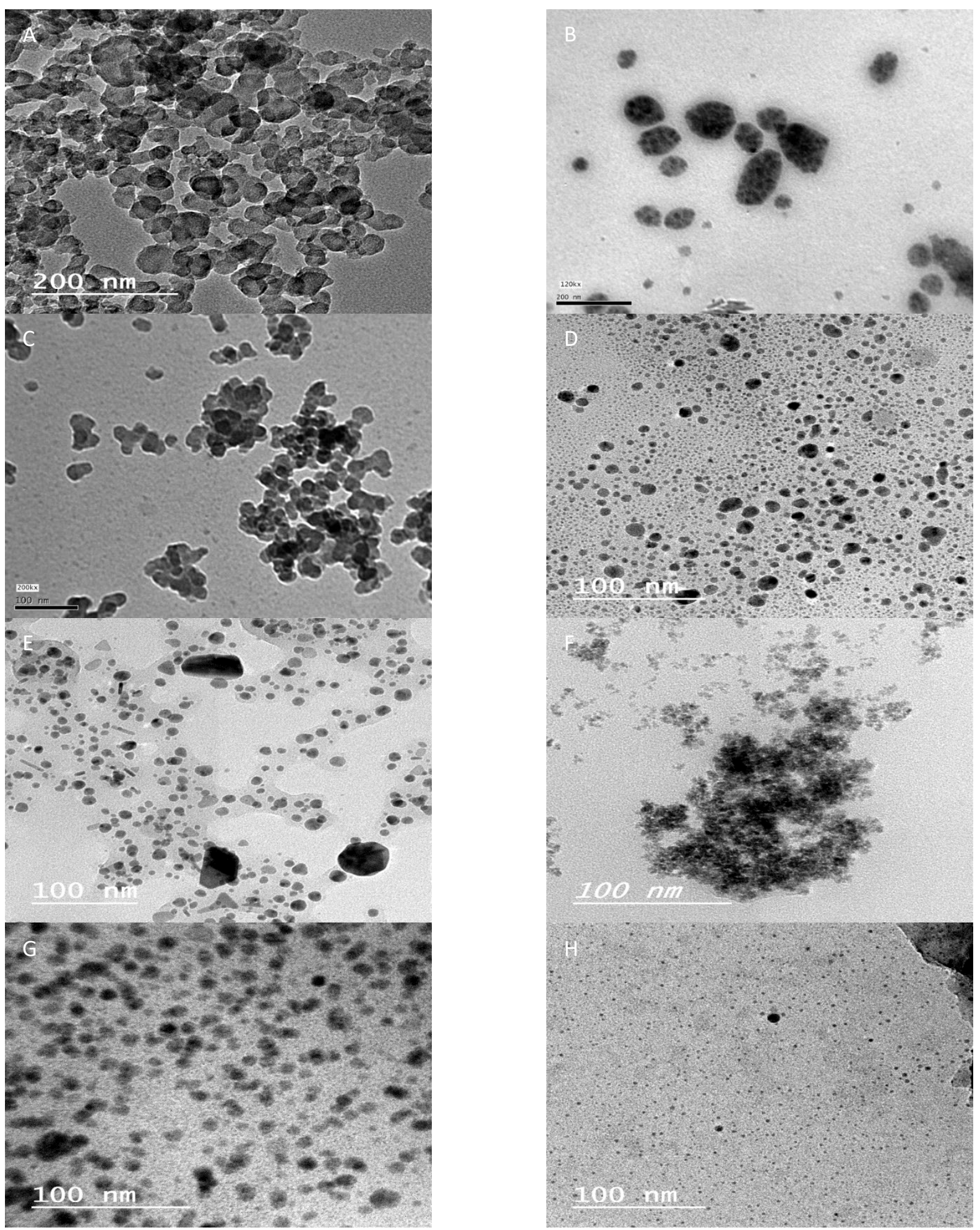

Figure 3. TEM image for Psidium guajava L. extract and synthesized AgNPs in both extracts at different $\mathrm{pH}$.

(a) TEM image of Psidium guajava L.in water extract; (b) TEM image of Psidium guajava L.in ethanol extract; (c) TEM image of AgNPs in water extract at pH 6; (d) TEM image of AgNPs in ethanol extract at pH 6; (e) TEM image of AgNPs in water extract at $\mathrm{pH} 8$; (f) TEM image of AgNPs in ethanol extract at $\mathrm{pH} 8$; (g) TEM image of AgNPs in water extract at $\mathrm{pH}$ 10; (h) TEM image of AgNPs in ethanol extract at $\mathrm{pH} 10$.

\subsection{Characterization of functionalized cotton fabric.}

\subsubsection{Extraction concentration effect.}

Cotton fabrics have been treated with Psidium guajava L. extract in water and alcohol in the presence and absence of AgNPs with different concentrations $(25,50,75$, and $100 \%)$ at 
$\mathrm{pH} 4,70^{\circ} \mathrm{C}$ for $15 \mathrm{~min}$., and it was found that increasing any extraction concentration cause increasing in UV protection factor (UPF) values even in presence or absence of AgNPs (Table 1). Furthermore, alcoholic extraction imparts a higher UPF value to treated fabric than water extraction with the same concentration because of the extract's component. The ethanolic extract provides more phenolic components that can react with cellulose through the crosslinker, which provides a high UPF value.

Besides, these compounds can reduce $\mathrm{AgNO}_{3}$ to $\mathrm{AgNPs}$ in both extracts, but as these compounds exhausted in the synthesis of AgNPs, their effect on the UPF was decreased, which led to decreasing the UPF value of the treated fabrics with Psidium guajava L. in both extracts in the presence of AgNPs with any concentration (25, 50, 75, and $100 \%$ ) comparing to those fabrics treated with Psidium guajava L. in both extracts in the absence of AgNPs with the same concentration.

From another point of view, the UPF values for all treated fabrics have been decreased after washing and losing UPF properties. As reported [83], UPF limits of the treated garment for UV-protection should be at least 40 50+, but it was less than these values after washing.

So treated cotton fabrics with Psidium guajava L. in both extracts in the presence or absence of AgNPs at $\mathrm{pH} 4,70^{\circ} \mathrm{C}$ for $15 \mathrm{~min}$., can be exhibit a UV-protection property, but it was lost this property after washing.

\subsubsection{Effect of $\mathrm{pH}$.}

When the cotton fabric was treated with Psidium guajava L. extract in water and alcohol in the presence and absence of AgNPs at different $\mathrm{pH}$, i.e., 4, 6, 8, and 10 with $100 \%$ extract at $70^{\circ} \mathrm{C}$ for $15 \mathrm{~min}$., it was found that cotton fabrics have a highest UV protection factor (UPF) when treated at pH 8 with both alcoholic and aqueous extractions (see Table 2).

Table 1. UV protection factor (UPF) for treated fabrics with Psidium guajava L. in water and alcoholic extract at different $\mathrm{pH}$.

\begin{tabular}{|c|c|c|c|c|}
\hline \multirow{2}{*}{$\begin{array}{c}\text { Extraction } \\
\text { process }\end{array}$} & \multirow{2}{*}{ Concentration (\%) } & \multirow{2}{*}{ AgNPs } & \multicolumn{2}{|c|}{ UPF } \\
\hline & & & Before washing & After washing \\
\hline \multirow{8}{*}{ Water extract } & \multirow{2}{*}{25} & presence & 4.1 & 0.8 \\
\hline & & absent & 29.5 & 5.4 \\
\hline & \multirow[b]{2}{*}{50} & presence & 8.3 & 1.7 \\
\hline & & absent & 59.2 & 12.3 \\
\hline & \multirow{2}{*}{75} & presence & 9.3 & 2.9 \\
\hline & & absent & 66.1 & 20.5 \\
\hline & \multirow{2}{*}{100} & presence & 11.6 & 4.2 \\
\hline & & absent & 82.5 & 29.7 \\
\hline \multirow{8}{*}{ Alcohol extract } & \multirow{2}{*}{25} & presence & 10.7 & 3.9 \\
\hline & & absent & 41.2 & 15.1 \\
\hline & \multirow{2}{*}{50} & presence & 17.0 & 6.3 \\
\hline & & absent & 65.7 & 24.2 \\
\hline & \multirow{2}{*}{75} & presence & 18.4 & 6.9 \\
\hline & & absent & 71.2 & 26.8 \\
\hline & \multirow{2}{*}{100} & presence & 22.6 & 8.4 \\
\hline & & absent & 87.3 & 32.4 \\
\hline
\end{tabular}

Cotton fabric was treated with Psidium guajava L. extract in water and alcohol in the presence and absence of AgNPs with different extraction concentrations $(25,50,75$, and $100 \%), \mathrm{pH} 4$ at $70^{\circ} \mathrm{C}$ for $15 \mathrm{~min}$.

This means that the increase of $\mathrm{pH}$ causes an increase in the UV protection factor of the treated fabric until $\mathrm{pH} \mathrm{8,} \mathrm{while,} \mathrm{when} \mathrm{the} \mathrm{pH}$ increases to 10 for aqueous extraction, it was found a descent in the UV protection of the treated fabrics. Whereas for the alcoholic extract, increasing the $\mathrm{pH}$ value to 10 resulted in the aggregation of the extract's molecules. This means that the alcoholic extract does not tolerate elevated alkaline degrees. 
Washing treated fabrics led to a decrease in their UPF values as the unreacted materials were lost. But it is clear that even after washing treated fabrics with both extracts at $\mathrm{pH} 8$ and 10 still provide a good UPF value, but treated fabric at $\mathrm{pH} 8$ has higher UPF values than those treated at $\mathrm{pH} 10$.

Besides, treated fabrics Psidium guajava L. extract in both extracts in the presence of AgNPs at different $\mathrm{pH}$, i.e., 4, 6, 8, and 10 , with $100 \%$ extract at $70^{\circ} \mathrm{C}$ for $15 \mathrm{~min}$. decreasing their UPF values before or after washing.

Table 2. UV protection factor (UPF) for treated fabrics with Psidium guajava L. in water and alcoholic extract

\begin{tabular}{|c|c|c|c|c|}
\hline \multirow{2}{*}{$\begin{array}{c}\text { Extraction } \\
\text { process }\end{array}$} & \multirow{2}{*}{ pH } & \multirow{2}{*}{ AgNPs } & \multicolumn{2}{|c|}{ UPF } \\
\hline & & & Before washing & After washing \\
\hline \multirow{8}{*}{ Water extract } & \multirow{2}{*}{4} & presence & 11.6 & 4.2 \\
\hline & & absent & 82.5 & 29.7 \\
\hline & \multirow{2}{*}{6} & presence & 4.1 & 1.4 \\
\hline & & absent & 85.3 & 42.1 \\
\hline & \multirow[b]{2}{*}{8} & presence & 2.9 & 1.0 \\
\hline & & absent & 87.1 & 55.6 \\
\hline & \multirow{2}{*}{10} & presence & 1.9 & 0.3 \\
\hline & & absent & 77.2 & 41.9 \\
\hline \multirow{8}{*}{ Alcohol extract } & \multirow{2}{*}{4} & presence & 22.6 & 8.4 \\
\hline & & absent & 87.3 & 32.4 \\
\hline & \multirow{2}{*}{6} & presence & 12.1 & 3.5 \\
\hline & & absent & 115.3 & 63.8 \\
\hline & \multirow{2}{*}{8} & presence & 8.9 & 3.7 \\
\hline & & absent & 266.9 & 111.0 \\
\hline & \multirow{2}{*}{10} & presence & 5.1 & 2.1 \\
\hline & & absent & 254.7 & 85.2 \\
\hline
\end{tabular}

Cotton fabric was treated with Psidium guajava L. extract in water and alcohol in the presence and absence of AgNPs at $100 \%$ extract and different $\mathrm{pH}(4,6,8$, and 10$)$ at $70^{\circ} \mathrm{C}$ for $15 \mathrm{~min}$.

\subsubsection{Effect of time.}

Treatment time optimization was carried out at different periods, i.e., 5, 10, 15, and 20 min, with $100 \%$ extract at $\mathrm{pH} 8$ at $70^{\circ} \mathrm{C}$. It was concluded from the findings that treated cotton fabrics with the highest UV protection value were observed after 15 min treatment period with both alcoholic and aqueous extractions (see Table 3). The explanation for the higher properties at 15 min treatment period could be attributed to the fabric arriving at the saturation point for Psidium guajava L. extract absorption, thus no further rise in extract absorption after 15 min of treatment time. After a time of $15 \mathrm{~min}$, the extracts seemed to start diffusing again in the treatment bath.

Washing treated fabrics led to a decrease in their UPF values as the unreacted materials were lost. Even after washing treated fabrics with both extracts for 10, 15 and $20 \mathrm{~min}$, it is clear that they still provide a good UPF value, but treated fabric for 15 min have higher UPF values than those treated for 10 or $20 \mathrm{~min}$.

Besides, treated fabrics Psidium guajava L. extract in both extract in the presence of AgNPs for 10, 15 and 20 min with $100 \%$ extract at $\mathrm{pH} 8$ and $70^{\circ} \mathrm{C}$ provide decreasing their UPF values before or after washing.

\subsubsection{Effect of temperature.}

To optimize the treatment bath temperature, the treatment was carried out at different temperatures, i.e., $25,50,70$, and $100^{\circ} \mathrm{C}$, with $100 \%$ extract for $15 \mathrm{~min}$ at $\mathrm{pH}$. The results in 
Table 4 found that the highest UV protection was obtained when the treatment was done at $70^{\circ} \mathrm{C}$ for treated fabric with both alcoholic and aqueous extraction.

As seen in Table 4, treatment temperature greatly affects the adsorption of the Psidium guajava L. component onto the surface of cellulose fibers. Thus, as the treatment temperature increases, the adsorption increased. Therefore, increasing the treatment temperature by more than $70^{\circ} \mathrm{C}$ led to a slight increase in the UPF value with both extracts.

Washing treated fabrics led to a decrease in their UPF values as the unreacted materials were lost. Even after washing treated fabrics with both extracts at different temperatures, it is clear that they provide a good UPF value.

Table 3. UV protection factor (UPF) for treated fabrics with Psidium guajava L. in water and alcoholic extract at different immersed times before and after washing.

\begin{tabular}{|c|c|c|c|c|}
\hline \multirow{2}{*}{$\begin{array}{c}\text { Extraction } \\
\text { process }\end{array}$} & \multirow{2}{*}{ Time (min) } & \multirow{2}{*}{ AgNPs } & \multicolumn{2}{|c|}{ UPF } \\
\hline & & & Before washing & After washing \\
\hline \multirow{8}{*}{ Water extract } & \multirow{2}{*}{5} & presence & 2.0 & 0.6 \\
\hline & & absent & 60.4 & 17.3 \\
\hline & \multirow{2}{*}{10} & presence & 2.4 & 0.7 \\
\hline & & absent & 71.9 & 41.4 \\
\hline & \multirow{2}{*}{15} & presence & 2.9 & 1.0 \\
\hline & & absent & 87.1 & 55.6 \\
\hline & \multirow[b]{2}{*}{20} & presence & 2.9 & 1.0 \\
\hline & & absent & 87.9 & 50.5 \\
\hline \multirow{8}{*}{ Alcohol extract } & \multirow{2}{*}{5} & presence & 3.5 & 1.4 \\
\hline & & absent & 104.6 & 41.2 \\
\hline & \multirow{2}{*}{10} & presence & 6.2 & 1.6 \\
\hline & & absent & 186.1 & 77.5 \\
\hline & \multirow{2}{*}{15} & presence & 8.9 & 3.7 \\
\hline & & absent & 266.9 & 111.0 \\
\hline & \multirow{2}{*}{20} & presence & 9.0 & 2.0 \\
\hline & & absent & 270.8 & 102.3 \\
\hline
\end{tabular}

Cotton fabric was treated with Psidium guajava L. extract in water and alcohol in the presence and absence of AgNPs with $100 \%$ extract at a different time $(5,10,15$, and 20$)$ and $70^{\circ} \mathrm{C}$.

Table 4. UV protection factor (UPF) for treated fabrics with Psidium guajava L. with water and alcoholic extract at different treatment temperatures before and after washing.

\begin{tabular}{|c|c|c|c|c|}
\hline \multirow{2}{*}{$\begin{array}{c}\text { Extraction } \\
\text { process }\end{array}$} & \multirow{2}{*}{ Temperature (min) } & \multirow{2}{*}{ AgNPs } & \multicolumn{2}{|c|}{ UPF } \\
\hline & & & Before washing & After washing \\
\hline \multirow{8}{*}{ Water extract } & \multirow{2}{*}{25} & presence & 2.3 & 0.5 \\
\hline & & absent & 68.6 & 14.8 \\
\hline & \multirow{2}{*}{50} & presence & 2.4 & 0.5 \\
\hline & & absent & 72.3 & 15.9 \\
\hline & \multirow{2}{*}{70} & presence & 2.9 & 1.0 \\
\hline & & absent & 87.1 & 55.6 \\
\hline & \multirow{2}{*}{100} & presence & 3.7 & 1.5 \\
\hline & & absent & 89.2 & 45.4 \\
\hline \multirow{8}{*}{ Alcohol extract } & \multirow{2}{*}{25} & presence & 3.0 & 1.4 \\
\hline & & absent & 91.1 & 41.6 \\
\hline & \multirow{2}{*}{50} & presence & 4.5 & 2.6 \\
\hline & & absent & 135.9 & 78.0 \\
\hline & \multirow{2}{*}{70} & presence & 8.9 & 3.7 \\
\hline & & absent & 266.9 & 111.0 \\
\hline & \multirow{2}{*}{100} & presence & 9.4 & 3.8 \\
\hline & & absent & 276.0 & 88.0 \\
\hline
\end{tabular}

Cotton fabric was treated with Psidium guajava L. extract in water and alcohol in the presence and absence of AgNPs at different treatment temperatures $\left(25,50,70\right.$, and $\left.100{ }^{\circ} \mathrm{C}\right)$ with $100 \%$ extract at $\mathrm{pH} 8$ for $15 \mathrm{~min}$. 


\subsubsection{Mechanical properties.}

Tensile strength, break elongation, air permeability, roughness, and crease recovery angle was tracked for treated cotton fabrics before and after treatment with Psidium guajava L. extract in water and alcohol in the presence and absence of AgNPs at optimum conditions. The analyses obtained are presented in Table 5.

From the data in Table 5, It was clear that the physicomechanical properties of the treated cotton fabrics have been of utmost concern. The crease recovery angle (CRA) increases dramatically as the roughness of the surface, air permeability, tensile strength, and elongation at break reduces after treatment with Psidium guajava L. extract in water or alcohol with or without AgNPs at $\mathrm{pH} 8$ and $70^{\circ} \mathrm{C}$ for 15 min. This indicates that the Psidium guajava L. extract under investigation was extensively incorporated into the cotton fabric microstructure and, in doing so, a thin film was formed on the cotton surface and resolved to be responsible for these changes $[20,22,60,84]$.

The pre-crosslinking treatment of cotton fabric using citric acid catalyzed by sodium hypophosphite (SHP) as a dominant player was also to be emphasized in deciding the efficiency of the above-mentioned properties. The creation of covalent cross-linking bonds between neighboring cellulosic chains during this pre-treatment would impart rigidity to the cotton structure. Meanwhile, the citric acid and the reaction will degrade the cotton fabric chemically.

On the other side, the coated film can perceive reduced roughness and air permeability to fill the gaps on the surface of cellulosic fabrics. The major improvement of the crease recovery angle was most likely attributed to the formation of an intense network in the cotton structure which was strongly interlinked by covalent chemical bonding between cellulose chain and Psidium guajava L. extract component having carboxyl or hydroxyl groups.

Table 5. Physical and mechanical properties for treated fabrics with Psidium guajava L. in water and alcoholic extract.

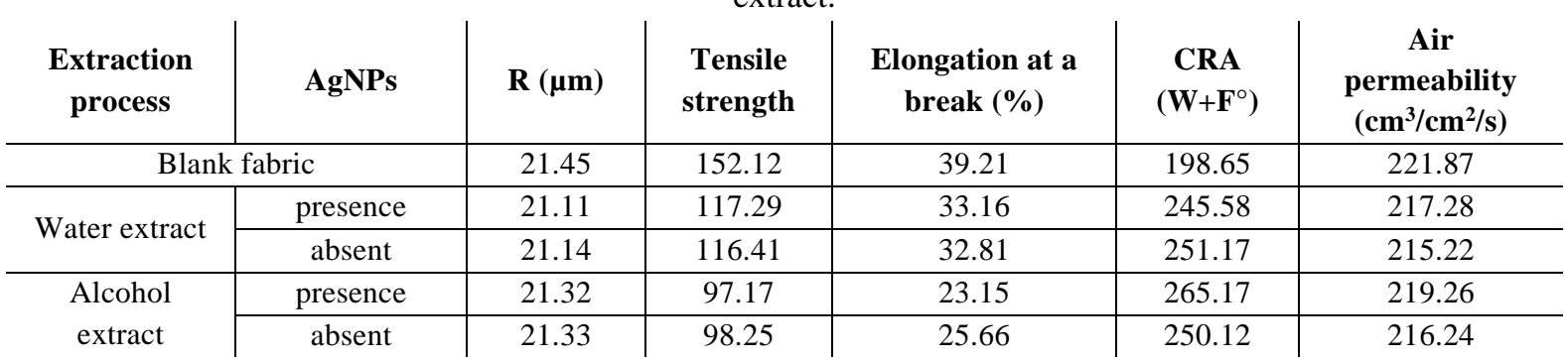

Cotton fabric was treated with Psidium guajava L. extract in water and alcohol in the presence and absence of AgNPs with $100 \%$ extract at $70^{\circ} \mathrm{C}, \mathrm{pH} 8$ for $15 \mathrm{~min}$.

\subsubsection{Antimicrobial properties.}

Microbial growth increases as the moisture and textile washing increases, and it reaches the maximum at neutral $\mathrm{pH}$ (7-8) [85]. Bacteria grow well in the dark except for the phototropic species. They are UV sensitive, and Light exposure can lead to pigment development, which can lead to colored fabric stains $[86,87]$.

Some mechanisms suggested for microbial cotton degradation include [86]: Fungal hypha (thread as a fungal element) can damage the cellulose secondary wall directly, and fungal fungus grows within a lumen; Bacterial cellulose degradation occurs from outside to inside, but cellulose cannot be directly digested. Cellulolytic microorganisms are the soluble cellulose enzymes produced by microbes and solubilized the cellulose, then eventually diffused into the 
cell; Carbon heterotopy bacteria degrade to short polysaccharide chains, hydrolyzed to shorter oligomers then cellobiose, and finally to D-glucose.

In practice, different words are used, i.e., Bactericide, fungicide, and biocide or bacteriostatic, fungistatic, and biostatic. The suffix code is used whenever the bacteria are destroyed, and when only the growth is stopped, the suffix static is used. If a substance compromises the validity of a microorganism, it is usually considered an antimicrobial.

In various ways, antimicrobial agents act, and the major ways are:

i. protein coagulation;

ii. disruption of cell membrane resulting in exposure, damage, or loss of the contents;

iii. elimination of free sulphydryl groups necessary for the functioning of enzymes; and

iv. A substance close to the enzyme's basic substratum diverts or misleads the necessary enzymes for the cell's metabolism and causes the cell to die.

A cell wall semi-permeable to the integrity of the cellular material consists of microorganisms. Bactericidal agents cause cell membrane rupture and cell damage. Wherever Bactericidal agents only prevent bacteria from multiplying, causing i) inhibiting cell wall synthesis, ii) alteration of cytoplasmic membrane permeability, iii) alteration of the physical and chemical protein and nucleic acids, iv) inhibition of enzyme activity and inhibition of protein and nucleic acid synthesis.

Furthermore, the Silver ions can destroy bacteria by strangling them in dry or wet atmospheres [88]. The highly biologically active silver ions bind the protein to bacterial membranes inside and outside, thereby inhibiting cell respiration and reproduction. At $\mathrm{pH} 8$, silver is 3-4 times active relative to $\mathrm{pH}$ 6. Silver products are bacterial-resistant but not as effective as fungus, mold, or mildew against other species [86].

Based on the inhibition zone system (as a qualitative method) against Escherichia coli (E. Coli; ATCC 25922) as a gram-negative bacteria, Staphylococcus aureus (S. aureus; ATCC 29213) as a gram-positive bacteria, and Candida albicans (C. albicans; ATCC 10231) as a fungus, treated cotton substrates were submitted for determination their antimicrobial activity as depicted in Table 6 and Figure 2.

Untreated cotton fabric (blank) has no inhibition effect on the two forms of bacteria and fungi tested. In contrast, treated fabrics with both Psidium guajava L. extracts in water and alcohol demonstrate a significant improvement in the antibacterial activity with good efficiency against the three forms of tested microbes (bacteria and fungi); 167.43, 277.65, and 132.63 $\mathrm{mm}^{2}$ for E. coli, S. aureus, and C. albicans, respectively.

This good activity is due to the presence of phytochemical compounds (phenolic acid, and flavonoids) in the Psidium guajava L. extracts. Besides, treated fabrics provide a higher efficiency against Gram-positive bacteria than Gram-negative bacteria., which is attributed to the difference in the cell wall structure of both examined bacteria strains.

The inhibition activity of the polyphenolic compounds on microbial RNA and DNA can be consistent with antimicrobial action. The microbial cytoplasmic membrane can also be depolarized. These compounds also provide antifungal activity as they inhibit ergosterol which is the main component in the cell membrane of fungi.

The antimicrobial results for treated fabrics revealed that Gram-negative bacteria displayed less sensitivity to both Psidium guajava L. extracts as compared with Gram-positive bacteria, while the fungal strains demonstrated a high sensitivity to both Psidium guajava L. 
extracts. This was primarily attributed to variations in the composition of their different cell walls. A single cell membrane, which is enclosed by a porous and thick cell wall that allows some bioactive components to spread through this, characterizes Gram-Positive Bacteria. Gram-negative bacteria are preferably comprised of three distinct layers covering certain bioactive components [89-91].

On the other hand, treated fabrics with Psidium guajava L. extract in aqueous and alcohol in the presence of AgNPs demonstrate outstanding values of antimicrobial tolerance.

It was also realized that the inhibition zone values of the fabrics treated with Psidium guajava L. extract in alcohol were higher than the corresponding results obtained with composite based on Psidium guajava L. extract in water. The interaction of AgNPs with the bacteria cells effectively occurs in the coating method. Psidium guajava L. extract containing different components that provide a good distribution and stabilization of AgNPs in the solution as well as on the cotton surface, thereby decreasing the binding ability of bacterial cells into the cotton surface $[17,33,57,71]$.

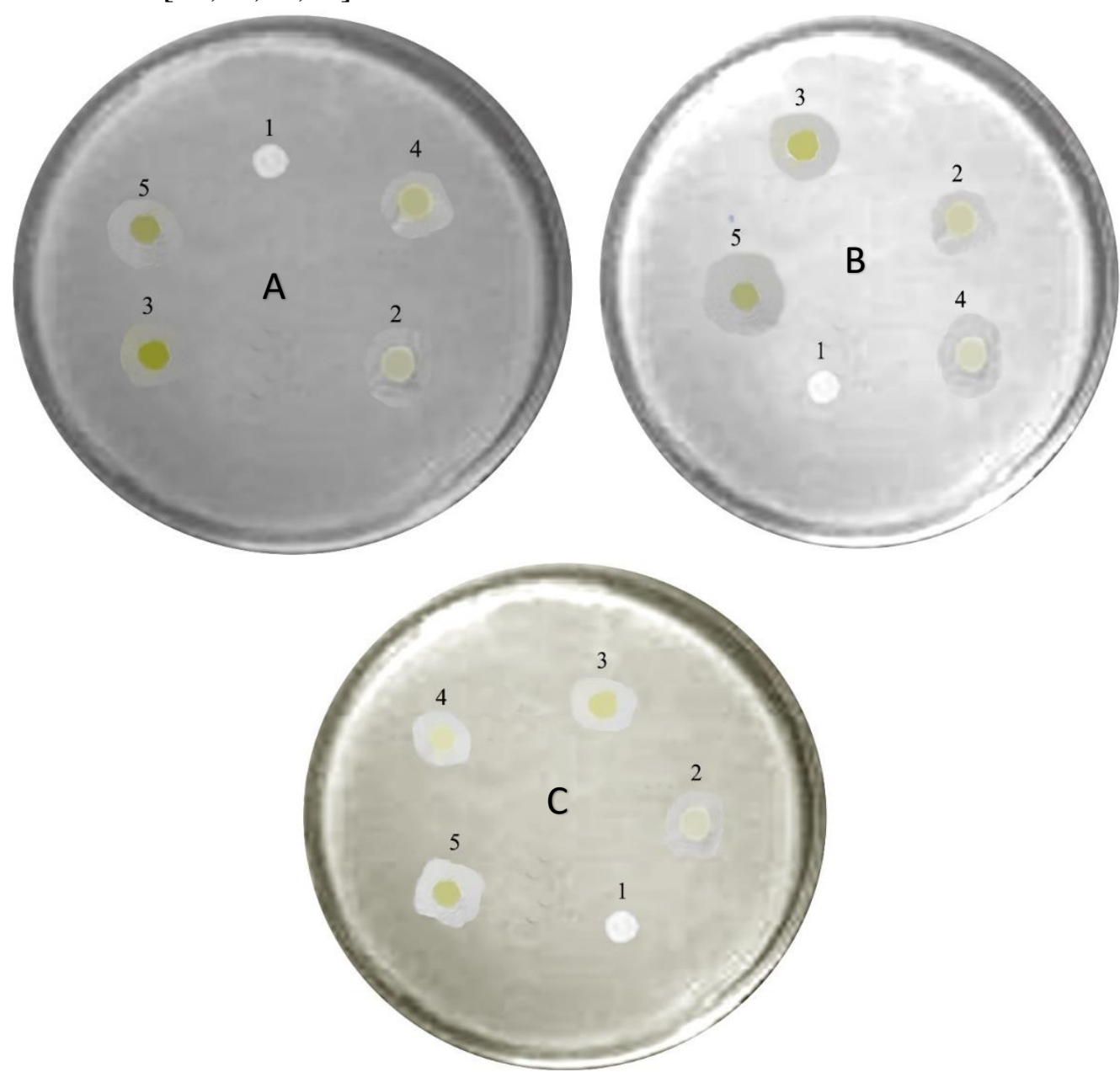

Figure 2. Antibacterial activity of treated fabrics with both Psidium guajava L. extracts in water and alcoholic solution in the presence and absence of AgNPs against three microbes. (a) E. coli as a gram-negative bacterium, (b) S. aureus as a gram-positive bacterium. (c) C. albicans is a fungus; 1) untreated fabric; 2) treated fabrics with water extract in the absence of AgNPs; 3) treated fabrics with water extract in the presence of AgNPs; 4) treated fabrics with alcoholic extract in the absence of AgNPs; 5) treated fabrics with alcoholic extract in the presence of AgNPs.

In the presence and absence of AgNPs against Escherichia coli, Staphylococcus aureus, and Candida albicans, the antimicrobial activity of both untreated and treated cotton substrates was checked using the counting process before and after different washing cycles. Table 6 
indicates the percentage of antimicrobial reduction in cotton fabrics. There is no inhibition of the reduction percent in untreated samples. Antimicrobial tolerance was present in the samples administered.

The bacteria reduction $\%$ for treated fabrics provides the same behavior against examined bacteria and fungi. The bacteria reduction $\%$ of treated fabrics after different washing cycles was investigated and decreased in microbial resistance until 10 washing cycles. Any further increase in washing cycles provides a small decrease in bacteria reduction \%. These results confirmed that treated fabrics have a good microbial resistance decreased by washing cycle but still prevent the bacteria growth more than the untreated one. Additional evidence that good production would come from these treated fabrics in the medical field.

Table 6. Zone inhibition area and bacteria reduction $\%$ for the antibacterial activity of treated fabrics with both

\begin{tabular}{|c|c|c|c|c|c|c|c|c|c|c|c|c|c|c|c|c|c|c|c|}
\hline \multirow{4}{*}{$\begin{array}{l}\text { Extracti } \\
\text { on } \\
\text { process }\end{array}$} & \multirow{4}{*}{ AgNPs } & \multicolumn{6}{|c|}{ E. coli (ATCC 25922) } & \multicolumn{6}{|c|}{ S. aureus (ATCC 29213) } & \multicolumn{6}{|c|}{ C. Albicans (ATCC 10231) } \\
\hline & & \multirow{3}{*}{$\mathbf{Z I} \mathbf{I}^{*}$} & \multicolumn{5}{|c|}{ Bacteria Reduction \% } & \multirow{3}{*}{$\mathbf{Z I} \mathbf{I}^{*}$} & \multicolumn{5}{|c|}{ Bacteria Reduction \% } & \multirow{3}{*}{$\mathbf{Z I}^{*}$} & \multicolumn{5}{|c|}{ Bacteria Reduction \% } \\
\hline & & & \multirow{2}{*}{\begin{tabular}{|c|} 
before \\
washin \\
$\mathbf{g}$
\end{tabular}} & \multicolumn{4}{|c|}{ after washing cycles } & & \multirow{2}{*}{\begin{tabular}{|c|} 
before \\
washin \\
$\mathbf{g}$ \\
\end{tabular}} & \multicolumn{4}{|c|}{ after washing cycles } & & \multirow{2}{*}{\begin{tabular}{|c|} 
before \\
washin \\
$\mathrm{g}$
\end{tabular}} & \multicolumn{4}{|c|}{ after washing cycles } \\
\hline & & & & 5 & 10 & 15 & 20 & & & 5 & 10 & 15 & 20 & & & 5 & 10 & 15 & 20 \\
\hline Blank & fabric & 0 & 0 & 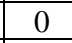 & 0 & 0 & 0 & 0 & 0 & 0 & 0 & 0 & 0 & 0 & 0 & 0 & 0 & 0 & 0 \\
\hline \multirow{2}{*}{$\begin{array}{c}\text { Water } \\
\text { extract }\end{array}$} & $\begin{array}{c}\text { presenc } \\
\mathrm{e}\end{array}$ & .5 & 13 & 67.74 & 41.10 & 39.34 & 37.26 & 6127.5 & 90.35 & 73.65 & 44.73 & 42.82 & 240.56 & 105.3 & 74.55 & 60.76 & 36.89 & 35.32 & 33.45 \\
\hline & absent & 88.8 & 62.91 & 51.27 & 31.13 & 29.80 & 28.23 & 3107.7 & 76.18 & 62.08 & 37.66 & 36.05 & 534.14 & 79.8 & 56.53 & 46.08 & 27.98 & 26.79 & 25.38 \\
\hline \multirow{2}{*}{$\begin{array}{c}\text { Alcohol } \\
\text { extract }\end{array}$} & reseng & 167.4 & 93.13 & 75. & 56.05 & 53.65 & 50.81 & 277.7 & 98.22 & 80.06 & 69.16 & 66.21 & 62.72 & 132.6 & 83.65 & 68.18 & 58.8 & 56.37 & 53.40 \\
\hline & & & & & & & & & & & & & & & & & & & \\
\hline
\end{tabular}

Zone inhibition $\left(\mathrm{mm}^{2}\right)=($ total area - fabric area $)$

\subsubsection{Antioxidant performance and UV-Protection (UPF).}

Phenols and flavonoids, which are the main component of Psidium guajava L. and known as a bioactive compound are naturally occurring antioxidants effect for human special in medical fabric because of their free radical scavenging activity of the oxygen species from their hydroxyl groups, which prevent cell deterioration and growth of new cells in the skin.

The antioxidant activity of the treated cotton fabrics with both Psidium guajava L. extracts in water and alcoholic in the presence and absence of AgNPs were examined for their antioxidant performance using 2,2-diphenyl-2-picrylhydrazyl (DPPH) and the results were illustrated in Table 7.

It was known that cotton fabric is a cellulosic material has an aliphatic hydroxyl functional group in their structure. This aliphatic hydroxyl group was resulting in poor antioxidative performance, the results in Table 7 provide no antioxidant performance due to the low sensitivity of DPPH to monitoring the very low antioxidative performance [5].

Thus, the cotton fabric treated with both Psidium guajava L. extracts in water and alcoholic in the presence and absence of AgNPs provides an antioxidant performance mainly attributed to the redox character of phenols and flavonoid compounds. These compounds have aromatic hydroxyl groups, which play a good role in forming free radicals.

Phenolic acids containing aromatic hydroxyl and carboxyl groups generally function as antioxidation agents by trapping free radicals, whereas flavonoids can scavenge those free radicals and chelate to metals such as AgNPs. Therefore, the treated cotton fabrics with both Psidium guajava L. extracts in water and alcoholic in the presence and absence of AgNPs can improve the antioxidant property, which allows them to be considered in medical applications $[50]$. 
Organic UV absorbers are uncolored organic aromatic molecules with combined dualbonded bonds that absorb UV energy with a 290-360 nm wavelength, which makes molecules excited. UV energy converts into UV molecular vibration energy. When the molecules return to the ground state, heat energy is emitted into the environment [92-94].

UV absorbers protect textile fabrics against chain fission and cross-linking reactions due to the photooxidation by polymers while reducing weathering rates for textile fibers under this safety process. UV absorbers must stay stable on UV exposure and reappear to their original shape after reaction to maintain long-lasting activity. If the molecules of UV absorbers are permanently transformed into their non-absorbing isomers, their UV absorbing properties are destroyed $[93,95]$.

In recent decades, synthetic organic UV absorbers have caused environmental concern, as numerous UV absorbers can produce toxic products by degradation, which may be bioaccumulative. Consequently, substantial work has been undertaken in recent years to study and incorporate UV-absorbing bioactive substances into modern environmentally-friendly garment manufacturing processes with UV safety characteristics. Bioactive compounds comprise natural finishing biodegradable, and limitless capital. Extracts from different plants as UVabsorbing bioactive compounds have been analyzed in this study.

Plant extracts commonly consist of flavonoids such as flavone, flavanol, luteolin, and baicalin, amino acids similar to mycrosphorine, tannins, lutein, and aloin [96-103]. Besides, most plant extracts have antimicrobial, anticancer, and antioxidant effects that enable them to be used to develop textiles related to medical, health, and hygienic materials.

In the last couple of years, much research has been underway on Psidium guajava Leave Extract, which has multiple positive attributes, including non-cytotoxicity, antimicrobial, ultraviolet absorption, wound healing, and other medicinal characteristics.

For textile application, Psidium guajava Leave Extract was applied to cotton fabric in the presence and absence of AgNPs using the pad-dry-cure method. The treated cotton fabric showed good UV protection properties at a value above 50, which was attributed to the presence of Psidium guajava Leave particles with the absorption maxima in the UVB region.

After ten washing cycles which proved the washing durability of the coating, a considerable amount of Psidium guajava Leave ingredients have been found to remain. This stressed the possible use of Psidium guajava Leave Extract for protection and biomedical multi-functional defensive clothing.

Furthermore, The UPF of untreated and treated cotton fabrics with both with Psidium guajava L. extracts in water and alcoholic in the presence and absence of AgNPs was recorded in Table 7 and provide that all treated fabrics have UPF values higher than untreated one which confirmed that, Psidium guajava L. extracts have a UV blocking material.

Table 7. Antioxidant activity of treated fabrics with both with Psidium guajava L. extracts in water and alcoholic in the presence and absence of AgNPs

\begin{tabular}{c|c|c|c|c|c}
\multirow{2}{*}{$\begin{array}{c}\text { Extraction } \\
\text { process }\end{array}$} & \multirow{2}{*}{ AgNPs } & \multicolumn{2}{c}{ Antioxidant performance (\%) } & \multicolumn{2}{c}{ UPF } \\
\cline { 3 - 6 } & Before washing & After washing & Before washing & After washing \\
\hline \multicolumn{2}{c}{ Blank fabric } & 0 & 0 & 0.1 & 0.1 \\
\hline \multirow{2}{*}{\begin{tabular}{c} 
Water extract \\
\cline { 2 - 6 }
\end{tabular}} & presence & $91 \pm 0.4$ & $68 \pm 1.1$ & 2.9 & 1.0 \\
\hline \multirow{2}{*}{$\begin{array}{c}\text { Alcohol } \\
\text { extract }\end{array}$} & presence & $87 \pm 0.8$ & $66 \pm 1.8$ & 87.1 & 55.6 \\
\cline { 2 - 6 } & absent & $80 \pm 0.7$ & $67 \pm 0.2$ & 266.9 & 3.7 \\
\end{tabular}


This effect could be attributed to the polyphenols and flavonoid compounds that can absorb UV radiation, making the treated fabrics more efficient to block the UV radiation and become protected and exhibiting the human skin a new property to saving them from the harmful ultraviolet radiation.

\section{Conclusion}

Psidium guajava Leaves consist of many bioactive compounds, including phenols, flavonoids, and essential oils, so Psidium guajava leaves extract was used as an eco-friendly process to impart multi-functional properties to cotton fabric. Psidium guajava Leaves were extracted using two solvents (water-ethanol). Both of them were used as reducing and stabilizing agents in the synthesis of silver nanoparticles. The phytochemicals of two solvents are responsible for the reduction of silver nanoparticles.

The UV-Vis spectra of synthesized silver nanoparticles using Psidium guava leaves extract showed that at low $\mathrm{pH}(4)$, there is no affinity to synthesis silver nanoparticles in the two extracts while increasing the $\mathrm{pH}$ to (6) cause starting the formation of silver nanoparticles. Therefore, the synthesis of silver nanoparticles was increased as the $\mathrm{pH}$ medium increased in both extracts. In addition to the formation of silver nanoparticles in alcoholic extraction is higher than in water extraction. It was also found that the particle size of silver nanoparticles decreases by increasing the $\mathrm{pH}$ medium. The particle size of silver nanoparticles in water extract was higher than those in the alcoholic extract at different $\mathrm{pH}(6,8$, and 10). TEM images are shown as a small and spherical form of a good distribution of silver nanoparticles.

The optimum condition of treated cotton fabric to get the highest UPF value and antimicrobial activity for both extractions in the absence and presence of silver nanoparticles was $100 \%$ concentration, $\mathrm{pH} 8$ at $70^{\circ} \mathrm{C}$ for $15 \mathrm{~min}$. Alcoholic extraction gives a higher UPF value to cotton fabric than water extraction at the same conditions.

The antimicrobial results for treated fabrics revealed that gram-negative bacteria displayed less sensitivity to both Psidium guajava Leaves as compared with gram-positive bacteria, while the fungal strains demonstrated a high sensitivity to both extractions. Moreover, treated fabrics with aqueous and alcoholic extraction in the presence of silver nanoparticles give a higher antimicrobial activity.

\section{Funding}

This research received no external funding.

\section{Acknowledgments}

The authors are gratefully grateful to acknowledge to National Research Centre (NRC) for the facilities provided. Thankful are also acknowledge to the faculty of Applied Arts, Benha University.

\section{Conflicts of Interest}

The authors declare no conflict of interest. 


\section{References}

1. Wu, Y.; Yang, Y.; Zhang, Z.; Wang, Z.; Zhao, Y.; Sun, L. Fabrication of cotton fabrics with durable antibacterial activities finishing by Ag nanoparticles. Text. Res. J. 2018, 89, 867-880, http://doi.org/10.1177/0040517518758002.

2. Nelson, G. Application of microencapsulation in textiles. Int. J. Pharm 2002, 242, 55-62, https://doi.org/10.1016/s0378-5173(02)00141-2.

3. Katewaraphorn, J.; Aldred, A.K. A study of microcapsules containing Psidium guajava leaf extract for antibacterial agent on cotton fabric. International Journal of Chemical Engineering and Applications 2016, 7, 27-31, http://doi.org/10.7763/ijcea.2016.V7.536.

4. Gutierrez, R.M.; Mitchell, S.; Solis, R.V. Psidium guajava: A review of its traditional uses, phytochemistry and pharmacology. J Ethnopharmacol 2008, 117, 1-27, http://doi.org/10.1016/j.jep.2008.01.025.

5. Rehan, M.; Ahmed-Farid, O.A.; Ibrahim, S.R.; Hassan, A.A.; Abdelrazek, A.M.; Khafaga, N.I.M.; Khattab, T.A. Green and sustainable encapsulation of guava leaf extracts (Psidium guajava 1.) into alginate/starch microcapsules for multi-functional finish over cotton gauze. ACS Sustainable Chemistry \& Engineering 2019, 7, 18612-18623, http://doi.org/10.1021/acssuschemeng.9b04952.

6. Maghimaa, M.; Alharbi, S.A. Green synthesis of silver nanoparticles from curcuma longa 1. and coating on the cotton fabrics for antimicrobial applications and wound healing activity. J. Photochem. Photobiol. B 2020, 204, 111806, http://doi.org/10.1016/j.jphotobiol.2020.111806.

7. Sriram, T.; Pandidurai, V. Synthesis of silver nanoparticles from leaf extract of Psidium guajava and its antibacterial activity against pathogens. International Journal of Current Microbiolgy and Applied Science 2014, 3, 146-152.

8. Pottathara, Y.B.; Grohens, Y.; Kokol, V.; Kalarikkal, N.; Thomas, S. Synthesis and processing of emerging twodimensional nanomaterials. In Nanomaterials synthesis, 2019, 1-25, http://doi.org/10.1016/b978-0-12-8157510.00001-8.

9. Basavegowda, N.; Idhayadhulla, A.; Lee, Y.R. Preparation of au and ag nanoparticles using artemisia annua and their in vitro antibacterial and tyrosinase inhibitory activities. Materials Science and Engineering: C 2014, 43, 58-64, http://doi.org/10.1016/j.msec.2014.06.043.

10. Rehan, M.; Elshemy, N.S.; Haggag, K.; Montaser, A.S.; Ibrahim, G.E. Phytochemicals and volatile compounds of peanut red skin extract: Simultaneous coloration and in situ synthesis of silver nanoparticles for multifunctional viscose fibers. Cellulose 2020, 27, 9893-9912, https://doi.org/10.1007/s10570-020-03452-8.

11. Rasool, S.; Raza, M.A.; Manzoor, F.; Kanwal, Z.; Riaz, S.; Iqbal, M.J.; Naseem, S. Biosynthesis, characterization and anti-dengue vector activity of silver nanoparticles prepared from azadirachta indica and citrullus colocynthis. Royal Society Open Science 2020, 7, 200540, https://doi.org/10.1098/rsos.200540.

12. Hassabo, A.G. New approaches to improving thermal regulating property of cellulosic fabric. Carbohydr. Polym. 2014, 101, 912-919, http://dx.doi.org/10.1016/j.carbpol.2013.10.006.

13. Hassabo, A.G.; Mohamed, A.L.; Wang, H.; Popescu, C.; Moller, M. Metal salts rented in silica microcapsules as inorganic phase change materials for textile usage. Inorganic Chemistry: An Indian Journal 2015, 10, 59-65.

14. Hassabo, A.G.; Mohamed, A.L. Enhancement the thermo-regulating property of cellulosic fabric using encapsulated paraffins in modified pectin. Carbohydr. Polym. 2017, 165, 421-428, http://doi.org/10.1016/j.carbpol.2017.02.074.

15. Hassabo, A.G.; Mohamed, A.L. Enhancement of thermo-regulating textile materials using phase change material (pcm). Evolution in Polymer Technology Journal 2019, 2, 180009.

16. Hassabo, A.G.; Mohamed, A.L. Novel flame retardant and antibacterial agent containing mgo nps, phosphorus, nitrogen and silicon units for functionalise cotton fabrics. Biointerface Research in Applied Chemistry 2019, 9 , 4272 - 4278, https://doi.org/10.33263/BRIAC95.272278.

17. Hassabo, A.G.; Mohamed, A.L.; Shaarawy, S.; Hebeish, A. Novel micro-composites based on phosphorylated biopolymer/polyethyleneimine/clay mixture for cotton multi-functionalities performance. Biosci. Res. 2018, 15, 2568-2582.

18. Mohamed, A.L.; Hassabo, A.G. Flame retardant of cellulosic materials and their composites. In Flame retardants, Visakh, P.M.; Arao, Y., Eds. Springer International Publishing: 2015; 247-314, http://dx.doi.org/10.1007/978-3-319-03467-6_10.

19. El-Sabour, M.A.; Mohamed, A.L.; El-Meligy, M.G.; Al-Shemy, M.T. Characterization of recycled waste papers treated with starch/organophosphorus-silane biocomposite flame retardant. Nord. Pulp Pap. Res. J. 2021, 36, 108-124, https://doi.org/10.1515/npprj-2020-0075.

20. Mohamed, A.L.; Hassabo, A.G.; Nada, A.A.; Abou-Zeid, N.Y. Properties of cellulosic fabrics treated by waterrepellent emulsions. Indian J. Fibre Text. Res. 2017, 42, 223-229.

21. Elshemy, N.S.; Nassar, S.H.; El-Taieb, N.M.; Shakour, A.A.A.; Elmekawy, A.M.; Hassabo, A.G. Effect of different fabrics types on the adsorption of air pollution in residential and industrial atmosphere in cairo-egypt. Letters in Applied NanoBioScience 2019, 9, 682 - 691, https://doi.org/10.33263/LIANBS84.682691.

22. Hebeish, A.; Shaarawy, S.; Hassabo, A.G.; El-Shafei, A. Eco-friendly multifinishing of cotton through inclusion of motmorillonite/chitosan hybrid nanocomposite. Der Pharma Chemica 2016, 8, 259-271. 
23. Mohamed, A.L.; El-Naggar, M.E.; Shaheen, T.I.; Hassabo, A.G. Novel nano polymeric system containing biosynthesized core shell silver/silica nanoparticles for functionalization of cellulosic based material. Microsys. Technol. 2016, 22, 979-992, http://doi.org/10.1007/s00542-015-2776-0.

24. Nada, A.A.; Hassabo, A.G.; Mohamed, A.L.; Mounier, M.M.; Abou Zeid, N.Y. Liposomal microencapsulation of rodent-repelling agents onto jute burlaps: Assessment of cytotoxicity and rat behavioral test. JAPS 2016, 6, 142-150, http://doi.org/10.7324/JAPS.2016.60822.

25. Abdelghany, A.M.; Meikhail, M.S.; El-Bana, A.A. Microbial activity and swelling behavior of chitosan/polyvinyl alcohol/sodium alginate semi-natural terpolymer interface containing amoxicillin for wound dressing applications. Biointerface Research in Applied Chemistry 2019, 9, 4368-4373, http://doi.org/10.33263/BRIAC95.368373.

26. Ali, G.W.; Abd El-Moez, S.H.; Abdel-Fattah, W.A. Synthesis and characterization of nontoxic silver nanoparticles with preferential bactericidal activity. Biointerface Research in Applied Chemistry 2019, 9, 46174623, http://doi.org/10.33263/BRIAC96.617623.

27. Mohamed, A.L.; Hassabo, A.G. Cellulosic fabric treated with hyperbranched polyethyleneimine derivatives for improving antibacterial, dyeing, $\mathrm{pH}$ and thermo-responsive performance. Int. J. Biol. Macromol. 2021, 170, 479-489, https://doi.org/10.1016/j.ijbiomac.2020.12.198.

28. Mohamed, A.L.; Soliman, A.A.F.; Ali, E.A.; Abou-Zeid, N.Y.; Nada, A.A. Hydrogel bioink based on clickable cellulose derivatives: Synthesis, characterization and in vitro assessment. Int. J. Biol. Macromol. 2020, 163, 888-897, https://doi.org/10.1016/j.ijbiomac.2020.07.068.

29. Hassabo, A.G.; Shaarawy, S.; Mohamed, A.L.; Hebiesh, A. Multifarious cellulosic through innovation of highly sustainable composites based on moringa and other natural precursors. Int. J. Biol. Macromol. 2020, 165 141155, https://doi.org/10.1016/j.ijbiomac.2020.09.125.

30. Amanzadi, B.; Mirzaei, E.; Hassanzadeh, G.; Mahdaviani, P.; Boroumand, S.; Abdollahi, M.; Hosseinabdolghaffari, A.; Majidi, R.F. Chitosan-based layered nanofibers loaded with herbal extract as wounddressing materials on wound model studies. Biointerface Research in Applied Chemistry 2019, 9, 3979-3986, http://doi.org/10.33263/BRIAC94.979986.

31. Arteaga-Robalino, A.; Castillo-Cabay, L.; Alcocér-Vallejo, R.; Santamaría-Aguirre, J. Drug shelf life estimation by non-isothermal treatments in dsc: Specific surface area effect. Biointerface Research in Applied Chemistry 2018, 8, 3289-3293.

32. Nada, A.A.; Hassabo, A.G.; Awad, H.M.; Fayad, W.; Shaffie, N.M.; Sleem, A.A.; Zeid, N.Y.A. Biomaterials based on essential fatty acids and carbohydrates for chronic wounds. JAPS 2015, 5, 13-21.

33. Aboelnaga, A.; Shaarawy, S.; Hassabo, A.G. Polyaconitic acid/functional amine/azo dye composite as a novel hyper-branched polymer for cotton fabric functionalization. Colloids Surf. B: Biointer. 2018, 172, 545-554, https://doi.org/10.1016/j.colsurfb.2018.09.012.

34. Mohamed, A.L.; Elmotasem, H.; Salama, A.A.A. Colchicine mesoporous silica nanoparticles/hydrogel composite loaded cotton patches as a new encapsulator system for transdermal osteoarthritis management. Int. J. Biol. Macromol. 2020, 164, 1149-1163, https://doi.org/10.1016/j.ijbiomac.2020.07.133.

35. Mohamed, A.L.; El-Naggar, M.E.; Hassabo, A.G. Preparation of hybrid nanoparticles to enhance the electrical conductivity and performance properties of cotton fabrics. Journal of Materials Research and Technology 2021, https://doi.org/10.1016/j.jmrt.2021.02.035.

36. Ibrahim, G.E.; Abdel-motaleb, A.F.; Mahmoud, E.R. Effect of some construction factors on fabrics used in traveling bags. Life Science Journal 2013, 10, 895 - 906.

37. El-Zawahry, M.M.; Hassabo, A.G.; Abdelghaffar, F.; Abdelghaffar, R.A.; Hakeim, O.A. Preparation and use of aqueous solutions magnetic chitosan / nanocellulose aerogels for the sorption of reactive black 5. Biointerface Research in Applied Chemistry 2021, 11, 12380 - 12402, https://doi.org/10.33263/BRIAC114.1238012402.

38. Jiao, C.; Li, T.; Wang, J.; Wang, H.; Zhang, X.; Han, X.; Du, Z.; Shang, Y.; Chen, Y. Efficient removal of dyes from aqueous solution by a porous sodium alginate/gelatin/graphene oxide triple-network composite aerogel. $J$. Polym. Environ. 2020, 28, 1492-1502, http://doi.org/10.1007/s10924-020-01702-1.

39. Bramel, S. Key trends in sportswear design. In Textiles in sport, Elsevier: 2005; 25-43,

40. ASTM Standard Test Method (D6603 - 00). Standard guide for labeling of uv-protective textiles. ASTM International: 2012.

41. BSI - BS EN 13758-1:2001-Textiles. Solar uv protective properties, part 1: Method of test for apparel fabrics. 2002.

42. BSI - BS EN 13758-2:2003-Textiles. Solar uv protective properties, part 2: Classification and marking of apparel. 2003.

43. Kamal, M.S.; Mahmoud, E.; Hassabo, A.G.; Eid, M.M. Effect of some construction factors of bi-layer knitted fabrics produced for sports wear on resisting ultraviolet radiation. Egy. J. Chem. 2020, 63, 4369 - 4378 , http://doi.org/10.21608/ejchem.2020.25922.2514.

44. Louris, E.; Sfiroera, E.; Priniotakis, G.; Makris, R.; Siemos, H.; Efthymiou, C.; Assimakopoulos, M. Evaluating the ultraviolet protection factor (upf) of various knit fabric structures. IOP Conference Series: Materials Science and Engineering 2018, 459, 012051, http://doi.org/10.1088/1757-899X/459/1/012051.

45. Zayed, M.; Othman, H.; Ghazal, H.; Hassabo, A.G. Psidium guajava leave extract as reducing agent for synthesis of zinc oxide nanoparticles and its application to impart multi-functional properties for cellulosic 
fabrics. Biointerface Research in Applied Chemistry 2021, 11, $13535 \quad$ - 13556, https://doi.org/10.33263/BRIAC115.1353513556.

46. Moodley, J.S.; Krishna, S.B.N.; Pillay, K.; Sershen; Govender, P. Green synthesis of silver nanoparticles from moringa oleifera leaf extracts and its antimicrobial potential. Advanc. Nat. Sci.: Nanosci. Nanotechnol. 2018, 9 , http://doi.org/10.1088/2043-6254/aaabb2.

47. ASTM Standard Test Method (E11 - 17). Standard specification for woven wire test sieve cloth and test sieves. ASTM International: 2017.

48. ISO 3310-1:2016. Test sieves. Technical requirements and testing. Test sieves of metal wire cloth. 2017.

49. ISO 565:1990. Test sieves — metal wire cloth, perforated metal plate and electroformed sheet — nominal sizes of openings. 2017.

50. Rehan, M.; Abdel-Wahed, N.A.M.; Farouk, A.; El-Zawahry, M.M. Extraction of valuable compounds from orange peel waste for advanced functionalization of cellulosic surfaces. ACS Sustainable Chemistry \& Engineering 2018, 6, 5911-5928, http://doi.org/10.1021/acssuschemeng.7b04302.

51. Aryal, S.; Baniya, M.K.; Danekhu, K.; Kunwar, P.; Gurung, R.; Koirala, N. Total phenolic content, flavonoid content and antioxidant potential of wild vegetables from western nepal. Plants (Basel, Switzerland) 2019, 8, http://doi.org/10.3390/plants8040096.

52. Fernandes, R.P.P.; Trindade, M.A.; Tonin, F.G.; Lima, C.G.; Pugine, S.M.P.; Munekata, P.E.S.; Lorenzo, J.M.; De Melo, M.P. Evaluation of antioxidant capacity of 13 plant extracts by three different methods: Cluster analyses applied for selection of the natural extracts with higher antioxidant capacity to replace synthetic antioxidant in lamb burgers. J Food Sci Technol 2016, 53, 451-460, http://doi.org/10.1007/s13197-015-1994-x.

53. Santhoshkumar, T.; Rahuman, A.A.; Jayaseelan, C.; Rajakumar, G.; Marimuthu, S.; Kirthi, A.V.; Velayutham, K.; Thomas, J.; Venkatesan, J.; Kim, S.-K. Green synthesis of titanium dioxide nanoparticles using Psidium guajava extract and its antibacterial and antioxidant properties. Asian Pacific Journal of Tropical Medicine 2014, 7, 968-976, http://doi.org/10.1016/s1995-7645(14)60171-1.

54. Singleton, V.L.; Rossi, J.A. Colorimetry of total phenolics with phosphomolybdic phosphotungstic acid reagents. Am J Enol Vitic 1965, 16, 144 - 158,

55. Australian/New Zealand Standard AS/NZS 4399:1996. Sun protective clothing — evaluation and classification. 1996.

56. Ibrahim, N.A.; Refaie, R.; Youssef, M.A.; Farouk, A. Proper finishing treatments for sun protective cotton containing fabrics. J. Appl. Polym. Sci. 2005, 97, 1024-1032, http://doi.org/10.1002/app.21840.

57. Mohamed, A.L.; Hassabo, A.G.; Shaarawy, S.; Hebeish, A. Benign development of cotton with antibacterial activity and metal sorpability through introduction amino triazole moieties and agnps in cotton structure pretreated with periodate. Carbohydr. Polym. 2017, 178, 251-259, http://doi.org/10.1016/j.carbpol.2017.09.024.

58. Mohamed, A.L.; Hassabo, A.G. Composite material based on pullulan/silane/zno-nps as ph, thermo-sensitive and antibacterial agent for cellulosic fabrics. Advances in Natural Science: Nanoscience and Nanotechnolgy 2018, 9, 045005, https://doi.org/10.1088/2043-6254/aaeee0.

59. Hassabo, A.G.; El-Naggar, M.E.; Mohamed, A.L.; Hebeish, A.A. Development of multi-functional modified cotton fabric with tri-component nanoparticles of silver, copper and zinc oxide. Carbohydr. Polym. 2019, 210, 144-156, https://doi.org/10.1016/j.carbpol.2019.01.066.

60. El-Naggar, M.E.; Hassabo, A.G.; Mohamed, A.L.; Shaheen, T.I. Surface modification of sio2 coated zno nanoparticles for multi-functional cotton fabrics. J. Colloid Interface Sci. 2017, 498, 413-422, http://dx.doi.org/10.1016/j.jcis.2017.03.080.

61. ASTM Standard Test Method (D5035-2011 (Reapproved 2019)). Standard test method for breaking force and elongation of textile fabrics (strip method). ASTM International: 2019.

62. AATCC Test Method (66-2014). Wrinkle recovery of fabric: Recovery angle method. In Technical Manual Method American Association of Textile Chemists and Colorists: 2017; 113-116.

63. ASTM Standard Test Method (D7127 - 13). Standard test method for measurement of surface roughness of abrasive blast cleaned metal surfaces using a portable stylus instrument1. ASTM International: West Conshohocken, PA, 2016.

64. ASTM Standard Test Method (D1388 - 14e1). Standard test methods for stiffness of fabrics. ASTM International: West Conshohocken, PA, 2016.

65. Khattab, T.A.; Mohamed, A.L.; Hassabo, A.G. Development of durable superhydrophobic cotton fabrics coated with silicone/stearic acid using different cross-linkers. Materials Chemistry and Physics 2020, 249, https://doi.org/10.1016/j.matchemphys.2020.122981.

66. AATCC Test Method (100-2019). Assessment of antimicrobial finishes on textile materials. In Technical Manual Method American Association of Textile Chemists and Colorists: 2019; 68.

67. Pargai, D.; Jahan, S.; Gahlot, M. Functional properties of natural dyed textiles. IntechOpen: 2020, https://doi.org/10.5772/intechopen.88933.

68. AATCC Test Method (147-2016). Antibacterial activity assessment of textile materials: Parallel streak. In Technical Manual Method American Association of Textile Chemists and Colorists: 2017; 275-276.

69. Hassabo, A.G.; Sharaawy, S.; Mohamed, A.L. Unsaturated fatty acids based materials as auxiliaries for printing and finishing of cellulosic fabrics. Biointerface Research in Applied Chemistry 2019, 9, 4284 - 4291 , https://doi.org/10.33263/BRIAC95.284291. 
70. Bershteein, E.M.; Vasil'eva, N.G.; Poliak, M.S. Standardization of the nutrient medium for determining the biological activity of a number of antibiotics by the diffusion-in-agar method. Antibiotiki 1983, 28, $250-254$.

71. Ibrahim, N.A.; Nada, A.A.; Hassabo, A.G.; Eid, B.M.; Noor El-Deen, A.M.; Abou-Zeid, N.Y. Effect of different capping agents on physicochemical and antimicrobial properties of zno nanoparticles. Chem. Pap. 2017, 71, 1365-1375, http://doi.org/10.1007/s11696-017-0132-9.

72. Abarca-Vargas, R.; Peña Malacara, C.F.; Petricevich, V.L. Characterization of chemical compounds with antioxidant and cytotoxic activities in bougainvillea $\mathrm{x}$ buttiana holttum and standl, (var. Rose) extracts. Antioxidants (Basel, Switzerland) 2016, 5, http://doi.org/10.3390/antiox5040045.

73. Iravani, S.; Korbekandi, H.; Mirmohammadi, S.V.; Zolfaghari, B. Synthesis of silver nanoparticles: Chemical, physical and biological methods. Res Pharm Sci 2014, 9, 385-406.

74. Rehan, M.; Mashaly, H.M.; Mowafi, S.; Abou El-Kheir, A.; Emam, H.E. Multi-functional textile design using in-situ ag nps incorporation into natural fabric matrix. Dyes Pigments 2015, 118, 9-17, http://doi.org/10.1016/j.dyepig.2015.02.021.

75. Rehan, M.; Barhoum, A.; Van Assche, G.; Dufresne, A.; Gätjen, L.; Wilken, R. Towards multi-functional cellulosic fabric: Uv photo-reduction and in-situ synthesis of silver nanoparticles into cellulose fabrics. Int. J. Biol. Macromol. 2017, 98, 877-886, https://doi.org/10.1016/j.ijbiomac.2017.02.058.

76. Rehan, M.; Mowafi, S.; Abdelmoez Aly, S.; Elshemy, N.S.; Haggag, K. Microwave-heating for in-situ Ag NPs preparation into viscose fibers. Eur. Polym. J. 2017, 86, 68-84, http://doi.org/10.1016/j.eurpolymj.2016.11.022.

77. Emam, H.E.; Mowafi, S.; Mashaly, H.M.; Rehan, M. Production of antibacterial colored viscose fibers using in-situ prepared spherical ag nanoparticles. Carbohydr. Polym. 2014, $110,148 \quad-\quad 155$, https://doi.org/10.1016/j.carbpol.2014.03.082.

78. Ajayi, E.; Afolayan, A. Green synthesis, characterization and biological activities of silver nanoparticles from alkalinized cymbopogon citratus stapf. Advanc. Nat. Sci.: Nanosci. Nanotechnol. 2017, 8, 015017, http://doi.org/10.1088/2043-6254/aa5cf7.

79. Sathyavathi, R.; Krishna, M.B.M.; Rao, D.N. Biosynthesis of silver nanoparticles using moringa oleifera leaf extract and its application to optical limiting. Journal of Nanoscience and Nanotechnology 2010, 10, 1-5, http://doi.org/10.1166/jnn.2010.3581.

80. Araújo, C.S.T.; Melo, E.I.; Alves, V.N.; Coelho, N.M.M. Moringa oleifera lam. Seeds as a natural solid adsorbent for removal of ag in aqueous solutions. J. Braz. Chem. Soc. 2010, 21, 1727-1732, https://doi.org/10.1590/S0103-50532010000900019.

81. Marcus, A.C.; Nwineewii, J.D. Studies on the crude extract of moringa oleifera leaf for preliminary identification of some phytochemicals and organic functions Journal of Applied Chemistry 2015, 8, 1-5, http://doi.org/10.9790/5736-081220105.

82. Kwaambwa, H.M.; Maikokera, R. A fluorescence spectroscopic study of a coagulating protein extracted from moringa oleifera seeds. Colloids and surfaces. B, Biointerfaces 2007, 60, 213-233, https://doi.org/10.1016/j.colsurfb.2007.06.015.

83. Ibrahim, N.A.; Nada, A.A.; Eid, B.M.; Al-Moghazy, M.; Hassabo, A.G.; Abou-Zeid, N.Y. Nano-structured metal oxides: Synthesis, characterization and application for multi-functional cotton fabric. Advanc. Nat. Sci.: Nanosci. Nanotechnol. 2018, 9, 035014, https://doi.org/10.1088/2043-6254/aadc2c.

84. Salama, M.; Hassabo, A.G.; El-Sayed, A.A.; Salem, T.; Popescu, C. Reinforcement of polypropylene composites based on recycled wool or cotton powders. J. Nat. Fiber 2017, 1-14, https://doi.org/10.1080/15440478.2017.1279582.

85. Sekar, N. Antibacterial finishes on cotton - developments. Colourage 2001, 48, 37-38.

86. Gupta, D.; Bhaumik, S. Antimicrobial treatments for textiles. Indian J. Fibre Text. Res. 2007, 32, $254-263$.

87. El-Shafei, A.; Shaarawy, S.; Motawe, F.H.; Refaei, R. Herbal extract as an ecofriendly antibacterial finishing of cotton fabric. Egy. J. Chem. 2018, 61, 317-327, http://doi.org/10.21608/ejchem.2018.2621.1209.

88. Mirjalili, M.; Yaghmaei, N.; Mirjalili, M. Antibacterial properties of nano silver finish cellulose fabric. Journal of Nanostructure in Chemistry 2013, 3, 43, http://doi.org/10.1186/2193-8865-3-43.

89. Biswas, B.; Rogers, K.; McLaughlin, F.; Daniels, D.; Yadav, A. Antimicrobial activities of leaf extracts of guava (Psidium guajava 1.) on two gram-negative and gram-positive bacteria. Int J Microbiol 2013, 2013, 1-7, http://doi.org/10.1155/2013/746165.

90. Metwally, A.M.; Omar, A.A.; Harraz, F.M.; El Sohafy, S.M. Phytochemical investigation and antimicrobial activity of Psidium guajava 1. Leaves. Pharmacogn Mag 2010, 6, 212-218, http://doi.org/10.4103/09731296.66939.

91. Dhiman, A.; Nanda, A.; Ahmad, S.; Narasimhan, B. In vitro antimicrobial activity of methanolic leaf extract of Psidium guajava 1. Journal of pharmacy \& bioallied sciences 2011, 3, 226-229, http://doi.org/10.4103/09757406.80776.

92. Das, B.R. Uv radiation protective clothing The Open Textile Journal 2010, 3, 14-21,

93. Mavrić, Z.; Tomšič, B.; Simončič, B. Recent advances in the ultraviolet protection finishing of textiles. Tekstilec 2018, 61, 201-220, https://doi.org/10.14502/Tekstilec2018.61.201-220.

94. Alebeid, O.K.; Zhao, T. Review on: Developing uv protection for cotton fabric. J. Text. Inst. 2017 108, 2027 2039, https://doi.org/10.1080/00405000.2017.1311201.

95. Gayathri, N.; Das, S. UV protection finishes and its effects on textiles. Asian Dyer 2018, 47 - 52. 
96. Janarthanan, M.; Senthil Kumar, M. The properties of bioactive substances obtained from seaweeds and their applications in textile industries. J. Indust. Text. 2017, 48, 361-401, http://doi.org/10.1177/1528083717692596.

97. Shabbir, M.; Jameel, L.; Mohammad, F. Economically viable uv-protective and antioxidant finishing of wool fabric dyed with tagetes erecta flower extract: Valorization of marigold. Industrial Crops and Products 2018, 119, http://doi.org/10.1016/j.indcrop.2018.04.016.

98. Subramani, K.; Kolathupalayam Shanmugam, B.; Rangaraj, S.; Palanisamy, M.; Periasamy, P.; Venkatachalam, R. Screening the uv-blocking and antimicrobial properties of herbal nanoparticles prepared from aloe vera leaves for textile applications. IET Nanobiotechnol. 2018, 12, 459-465, http://doi.org/10.1049/iet-nbt.2017.0097.

99. Zhou, Y.; Yang, Z.Y.; Tang, R.C. Bioactive and uv protective silk materials containing baicalin - the multifunctional plant extract from scutellaria baicalensis georgi. Materials science \& engineering. C 2016, 67, 336344, http://doi.org/10.1016/j.msec.2016.05.063.

100. Koh, E.; Hong, K. Functional fabric treatment using tannic acid and extract from purple-fleshed sweet potato. Text. Res. J. 2016, 87, http://doi.org/10.1177/0040517516639829.

101. Saewan, N.; Jimtaisong, A. Photoprotection of natural flavonoids. JAPS 2013, 3, 129-141, http://doi.org/10.7324/japs.2013.3923.

102. Adeel, S.; Gulzar, T.; Azeem, M.; Rehman, F.; Saeed, M.; Hanif, I.; Iqbal, N. Appraisal of marigold flower based leutin as natural colourant for textile dyeing under the influence of gamma radiations. Radia. Phys. Chem. 2017, 130, 35-39, http://doi.org/10.1016/j.radphyschem.2016.07.010.

103. Ghayempour, S.; Montazer, M.; Mahmoudi Rad, M. Simultaneous encapsulation and stabilization of aloe vera extract on cotton fabric for wound dressing application. RSC Adv. 2016, 6, 111895-111902, http://doi.org/10.1039/c6ra22485g. 